Portland State University

PDXScholar

2-12-1993

\title{
Lola G. Baldwin and the Professionalization of Women's Police Work, 1905-1922
}

Gloria Elizabeth Myers

Portland State University

Follow this and additional works at: https://pdxscholar.library.pdx.edu/open_access_etds

Part of the History Commons

Let us know how access to this document benefits you.

\section{Recommended Citation}

Myers, Gloria Elizabeth, "Lola G. Baldwin and the Professionalization of Women's Police Work, 1905-1922" (1993). Dissertations and Theses. Paper 4687.

https://doi.org/10.15760/etd.6571

This Thesis is brought to you for free and open access. It has been accepted for inclusion in Dissertations and Theses by an authorized administrator of PDXScholar. Please contact us if we can make this document more accessible: pdxscholar@pdx.edu. 
AN ABSTRACT OF THE THESIS OF Gloria Elizabeth Myers for the Master of Arts in History presented February 12, 1993.

Title: Lola G. Baldwin and the Professionalization of Women's Police Work, 1905-1922.

APPROVED BY THE MEMBERS OF THE THESIS COMMITTEE:
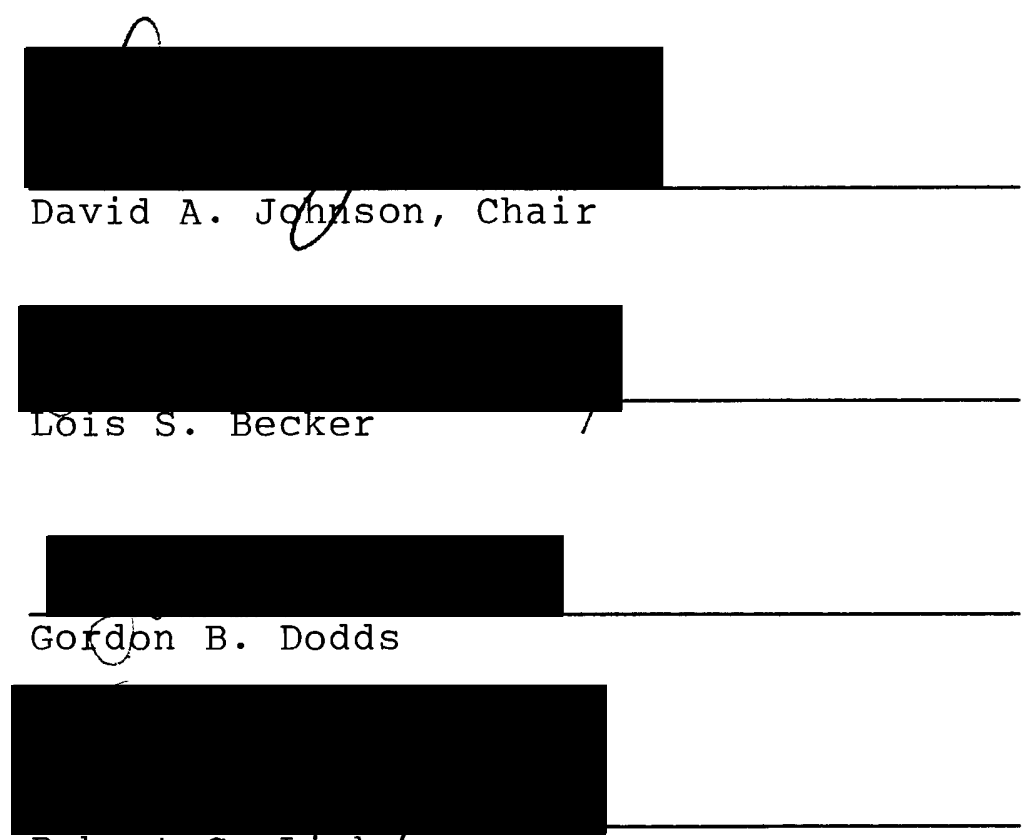

Robert C. Liebman

This thesis traces the emergence of the American policewomen's movement through the career of Portland, Oregon's Lola Greene Baldwin, the first such officer hired by a municipality. It recounts the conditions which marked Baldwin's transition from a volunteer moral purity worker to a professional urban vice detective. The thesis connects Baldwin and her new profession to the Progressive era's 
social hygiene impulse. It considers how government absorption of the social hygiene agenda influenced the enforcement attitudes and methods of the early policewoman. Further, this work looks at the way Baldwin functioned within the bureaucracies and political structures of her environment.

Baldwin's biographical history was obtained from her answers on a federal civil service application. The detective's original police department logs were a key element in researching her activities. Correspondence from the Portland city archives between the policewoman and five mayors and numerous police chiefs enhanced the information from her daily entries, as did a thorough perusal of contemporary newspaper items. Progressive-era city ordinances, reports of the Portland Vice Commission, and various memoranda of city council and local social hygiene committees also proved valuable. Miscellaneous personal documents and newspaper stories covering Baldwin's federal policing service during World War I were bolstered by articles from Social Hygiene.

Baldwin professionalized women's police work by convincing Portland to pay for vice prevention and investigation formerly sponsored by private charities. She developed professional standards and procedures such as detailed case files, periodic statistical reports, and a specialized parole system for female delinquents. The female 
vice officer freely offered her ideas to other cities and helped form a national association of policewomen in 1912 . Baldwin adopted social hygiene ideas through authoring laws which segregated females from sources of immorality in amusement and employment environments. The policewoman also championed detention homes for sexually precocious young women and special facilities for venereal cases. She fully accepted, moreover, social hygiene doctrine that prostitution was a medical as well as moral threat mandating complete abolition.

When city authorities lagged in pursuing prostitution abatement, Baldwin helped establish a vice commission which forced appropriate action. National recognition of the female detective's vice policing won her appointment as a World War I federal military training facility protective agent. This work involved the detention of thousands of West Coast women and girls on mere suspicion of immorality. Baldwin returned to her police job in Portland after her federal task ended in late 1920. Used to the complete social control afforded by martial law, however, the policewoman became discouraged by postwar moral laxity in the Rose city, and retired in early 1922 .

The American urban policewomen's movement was engendered as a government effort to maintain traditional female purity in the modernizing environment of the Progressive era. Baldwin personified the transition from 
religious-based notions which relied on moral suasion to methods of modern professional social control which codified traditional standards and made them relevant to prevailing cultural and social conditions. The policewoman used the agenda and momentum of the social hygiene movement to empower herself and her new profession.

Baldwin took advantage of growing acceptance of women as necessary partners in the management of a "parental" state. She embodied elements of "social feminism" because she believed that females were inherently different and needed state protection. Her insistence on professional equality with male cohorts, however, contradicted this pattern, as did her support of woman suffrage. Although Baldwin never reconciled to the vast cultural changes of her time, she left a proud legacy of professionalism to her daughters in modern law enforcement. 


\title{
LOLA G. BALDWIN AND THE PROFESSIONALIZATION OF WOMEN'S POLICE WORK, 1905-1922
}

\section{by}

GLORIA ELIZABETH MYERS

A thesis submitted in partial fulfillment of the requirements of the degree of

\author{
MASTER OF ARTS \\ in \\ HISTORY
}

Portland State University

1993 
TO THE OFFICE OF GRADUATE STUDIES:

The members of the Committee approve the thesis of Gloria Elizabeth Myers presented February 12, 1993.

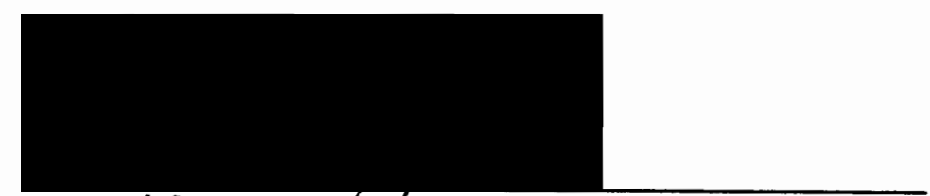

David A. Johnson, Chair

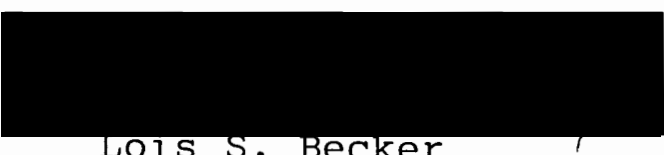

Lols S. Becker

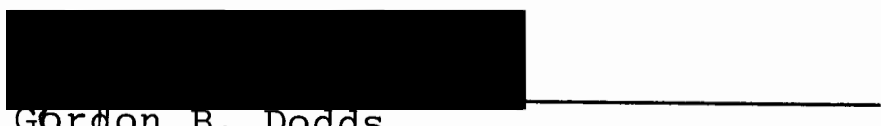

Gerqon B. Dodds

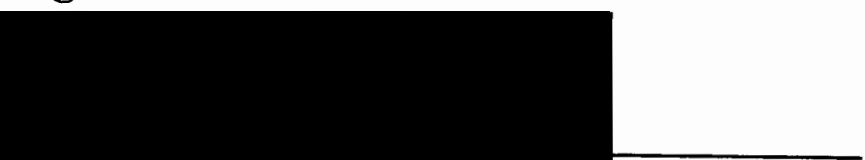

Robert C. Liebman

APPROVED :

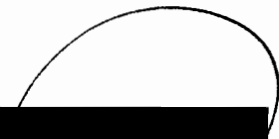

(1)

Bernard V. Burke, Chair, Department of History

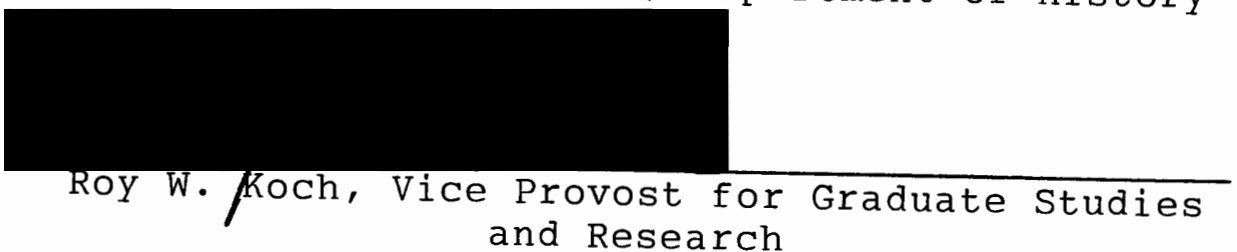


DEDICATION

For

Kim and David 


\section{PREFACE}

In 1920, social reformer and policing expert Raymond Fosdick called the infant policewomen's movement a significant step in the evolution of American law enforcement. Although the profession was only a dozen years old, he remarked that it had "proven its worth" in the active investigation and prevention of female vice crime. ${ }^{1}$ This thesis traces the emergence of the women's police through an examination of the career of Portland, Oregon's Lola G. Baldwin, the first such officer hired by an American city. It recounts her transition from volunteer moral purity worker to paid municipal vice officer and her connection to the Progressive era's social hygiene movement. It further considers how politicization of social hygiene at various levels of government influenced the genesis of the American policewoman.

Baldwin's police logs, diverse correspondence, and contemporary newspaper items form the core of this analysis. Its scope mirrors her active public policing career between the years 1905 and 1922. Its sources provide local examples of the national sexual morals crisis perceived by Progressive era reformers. Baldwin and her cohorts attempted to codify nineteenth century mores in an effort to stave off 
the immorality associated with urban-industrial modernity. This thesis demonstrates how she coped with the sexual, gender, and governmental politics which defined and threatened her existence within the traditionally male sphere of law enforcement. Similarly, it describes Baldwin's part in the creation of a new profession for women and her struggle to propagate and legitimize it. As a local case study with national implications, this effort seeks to enhance the perspectives of social, cultural, women's, and law enforcement history.

The first chapter of the thesis introduces Baldwin and details her transformation from a middle-class volunteer purity reformer to a paid municipal vice investigator influenced by the social hygiene movement. Chapter two shows how segments of Baldwin's policing program developed around elitist suspicions of urban working-class morals and the egalitarianism associated with emerging commercial amusements. The third chapter surveys her involvement with young female "sexual" delinquents and her role in building woman-run reformatories in which to segregate them. Chapter four describes Baldwin's part in the era's expansive battle against commercialized prostitution and portrays her involvement with the Portland Vice Commission. The conclusion describes Baldwin's legacy, analyzes her role in professionalizing women's police work, and places her contribution within the social and cultural context of the era. 
This thesis borrows much of its framework from the "shift in responsibility" model suggested by sociologists Robert Liebman and Michael Polen. In essence, it asks what conditions, i.e. social, political, cultural, or economic, caused government units to pay for services formerly performed by volunteer or privately-paid individuals. Insights into Baldwin's efforts to professionalize the policewoman come from the works of historians samuel walker and Don S. Kirschner.

Background on the sexual morality crisis in the post-Victorian period was obtained primarily from syntheses by David J. Pivar, and Estelle Freedman and John D'Emilio. Freedman's previous work on women's prison reform also proved valuable, as did Kathy Peiss's research on early twentieth-century amusements. Peggy Pascoe's treatise on female moral authority contributed to an understanding of Baldwin's apparent contradictions. For enhancement of information on Portland business and politics, E. Kimbark MacColl's standard history proved useful. Relevant primary documents and secondary sources were found in the city of Portland Archives, the Portland Police Historical Society, the oregon Historical Center, and the Portland State University and Multnomah County libraries.

This thesis was completed under the guidance of Dr. David A. Johnson, whom I thank for his input and understanding. I am also grateful to Dr. David A. Horowitz 
for encouragement and advice. In addition, I deeply appreciate the cooperative assistance of Steve Webber of the Portland City Archives, Sgt. Ralph o'Hara of the Portland Police Museum, and the staff of the Oregon Historical Center. 
TABLE OF CONTENTS

PAGE

PREFACE...............................

CHAPTER

I PURITY, REFORM, AND PROFESSIONAL

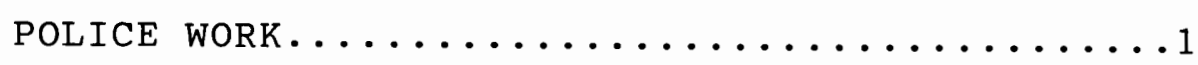

I I THE MENACE OF RAGTIME PORTLAND............. 19

II CONTROLLING THE FEMALE DELINQUENT..........40

IV THE POLICEWOMAN AND THE PROSTITUTE........63

V CONCLUSION: THE LEGACY OF THE POLICEWOMAN.....92

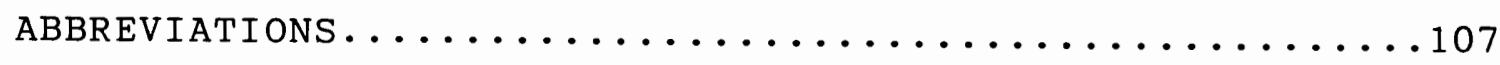

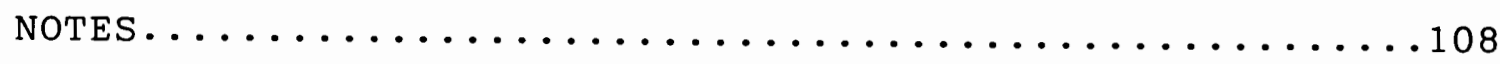

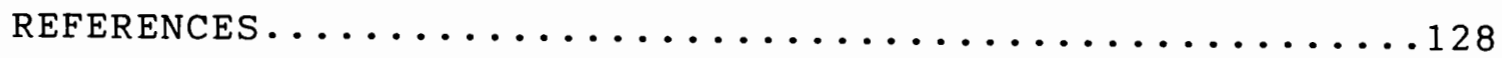




\section{CHAPTER I}

PURITY, REFORM, AND PROFESSIONAL POLICE WORK

As Portland, Oregon, prepared for its 1905 Lewis and Clark Exposition, the city's moral watchdogs wrestled with an irksome problem. "World's Fairs" to promote trade and development had become a fixture of American urban life by the early twentieth century. Their huge crowds and carnival atmosphere, however, won them a reputation for vice and immorality. The worst rumors concerned so-called "white slavery." Many Americans believed that a world-wide syndicate of procurers sent agents to such events to entice young female visitors into prostitution. By 1902, reports circulated that "hundreds" of girls had disappeared at recent expositions in Chicago and Buffalo. A group of New York moral purity advocates responded by organizing a National Exposition Travelers' Aid Committee to mount "preventive and protective" campaigns in host cities. After an initial effort in St. Louis in 1904, attention turned to Portland, where Jessie Honeyman of the Young Women's Christian Association (YWCA) agreed to start an affiliate program. 1

Raising money from local pledges, unused funds from the St. Louis effort, and a supplemental gift from New York 
society matron Helen Gould, Honeyman gathered a coalition board from the city's charities, churches, and synagogues. For director, the national Travelers' Aid recommended Lola Greene Baldwin. The recent Portland arrival had twenty years experience in volunteer moral purity work with women and girls. Baldwin started at a salary of $\$ 75$ per month, enabling her to leave a position at Woolworth's to devote full time to the task. Gratefully, the board granted her a free hand in designing a preventive and protective plan for girls during the exposition. 2

Portland promoters expected over a million visitors for the fair, but many came solely for the thousands of temporary jobs it spawned. Exposition employers sought attractive young women to fill low-skilled but highly visible positions in concessions, side-shows, and exhibit halls. The city's existing amusements also prepared to handle the overflow crowds. Saloons, nickelodeons, dance halls, pool rooms, skating rinks, and shooting galleries put a premium on pretty young females to attract business. Their advertisements often promised high wages for easy work. Baldwin viewed these places as intolerable "pitfalls" which lured young women into the world of vice. To counter this threat, her volunteers clipped and investigated suspicious newspaper advertisements, and exposed cases of bogus or morally dangerous employment in the press. As a safety measure, Baldwin obtained promises from reputable businesses to employ girls referred by Travelers' Aid. 3 
Many of the young women arriving in Portland were rural migrants. Unused to the subtle traps of the city, they demanded special attention. Travelers' Aid found that advertised rental rooms frequently were located above saloons, brothels, or other questionable businesses. In response, Baldwin's volunteer vice squad compiled lists of approved and disapproved lodgings, carefully noting moral conditions as well as physical safety factors such as hall and stairway lighting. These lists were freely available to arriving girls at rail and boat terminals. To ease the situation, both the YWCA and the Volunteers of America provided temporary rooms for those who could not immediately find suitable housing. 4

Baldwin quickly won pledges from the city's saloonmen and brothel keepers to report or discourage underage girls who sought work in their establishments. The directness of her approach won the respect of many proprietors, who agreed to cooperate with the understanding that the Travelers' Aid supervisor "would never betray a confidence." This pragmatic compromise helped Baldwin fulfill the limited and temporary agency's stated purpose of preventing young women from falling into prostitution during the exposition. "We do not expect to eradicate the social evil in Portland," she remarked at an April 1905 meeting, "but we do expect to improve it." 5 
Setting her volunteers to work well in advance of the June 15 opening day, Baldwin stationed orange-ribboned Travelers' Aid personnel at the train depot and docks to intercept early arrivals. Workers were prepared to offer any type of help to the female traveler. In addition to lists of approved lodgings and employment, Baldwin had arranged for free medical aid through Good Samaritan Hospital, vouchers for temporary meals and shelter, and the cooperation of transportation companies on ticket problems. Local mothers applauded the group's thorough surveillance of the fairgrounds and other amusements. Baldwin's stature in the community was further enhanced when the new Portland Juvenile Court named her a girls' probation officer. Not long after, by her own account, newly-elected mayor Harry Lane presented her a police star to carry as a token of the city's recognition of her vice-prevention work. 6

Baldwin's personal history explained much of the empathy she expressed for young women out on their own. Unlike many of the sheltered society women who filled the ranks of her volunteers, she had been required to take care of herself at an early age. Born in Elmira, New York, in 1860, she was educated through high school in the city of Rochester. Her father's death in 1877 forced Baldwin to prepare for making a living at the age of seventeen. Passing the examination for New York state teaching credentials, she taught for several years in Monroe County. In 1880 , the New 
Yorker migrated west to Lincoln, Nebraska to take a high school position. Four years later, she met and wed LaGrand Baldwin. Rejecting custom, she continued to work after marriage. Since married women were not allowed to teach, the young bride took a job in the public lands office. 7

During the next decade, Baldwin gave birth to two sons. She also became involved in juvenile social work, volunteering her services at three Lincoln institutions which cared for "wayward" girls and young women. The first, the Lincoln Children's Home, housed orphaned, abandoned, and troubled youth. The second, the Home for the Friendless, offered an "educative and preventive" program for unmarried girls or young women who were pregnant or sexually delinquent. The institution taught victorian mores which discouraged any further sexual activity until marriage, and offered job training to prevent residents from resorting to prostitution. The third facility, the Nebraska Rescue Home, vigorously sought to bring confirmed prostitutes back to respectable lives through an intensive program of moral education and employment training. ${ }^{8}$

When the family moved east in 1892 , Baldwin performed similar volunteer work in Boston, Yonkers, Norfolk, and Providence. But in 1904, LaGrand Baldwin accepted a position as manager of the E. P. Charlton notions store in Portland, Oregon. His wife soon found office work at Woolworth's and resumed social work activities as a board member of the 
city's Florence Crittenton Rescue Home. For twenty years, Lola Baldwin had listened to the stories of girls and women who had fallen into sexual vice and had an extensive knowledge of the circumstances of their lives. When the Travelers' Aid asked her to direct its preventive and protective work for the exposition, therefore, it obtained a woman well acquainted with urban vice traps. 9

With the Lewis and Clark Exposition in full swing in the summer of 1905, the success of the Travelers' Aid Committee became apparent. By the end of July, hundreds of women and girls voluntarily had sought the agency's assistance. Baldwin located other young women whose anxious families had reported them "missing." She shepherded still others through the criminal courts and kept close watch on them afterwards. Mayor Lane's office received nationwide congratulations for the protective work being done in conjunction with the fair. The mayor added his personal appreciation at the July Travelers' Aid meeting, when he unveiled extensive plans to clean up the city's vice district. Representatives of the Municipal Court and the Boys and Girls Aid Society expressed similar approval of Baldwin's work. The Travelers' Aid supervisor later thanked Lane for his remarks and lauded his own "rousing" anti-vice speech. 10

With statistical skills learned during her land office employ, Baldwin recorded case data in a cross-referenced 
card file. This system enabled her to make periodic statements to the press concerning the number and kind of incidents handled. The published reports, however, were always of a general nature. Unless specifically requested by the police or courts, personal information about the subjects was never released. By late August, these statistics confirmed a trend which Baldwin had suspected for weeks: the majority of vice-related cases concerned not out-of-town visitors, but local women and girls. Such information led Baldwin and other protective workers to conclude that their efforts would have to continue once the fair ended. 11

When the grand exhibition closed its gates in october 1905, Portland newspapers published what was to have been Baldwin's final report. During the exposition, she stated, Traveler's Aid had served over 1500 women and girls, a third of whom had been placed in "safe" employment. Mayor Lane, the chief of police, and the courts generally agreed that the organization had "had a restraining influence upon procurers and other men of evil classes" before and during the fair. Baldwin's pursuit of men who impregnated young women, moreover, produced several forced marriages and a number of well-publicized prosecutions. She believed that legal action not only punished the wrongdoers, but served as a warning to leave Portland's girls alone. But, if the agency ended its preventive work, Baldwin's report concluded, conditions would soon be "as bad as ever."12 
In reality, conditions for the city's young women worsened. Fair-related employment evaporated, leaving large numbers without means to return home, or develop skills suitable for other jobs. Safe unskilled positions were rare, and even "good" young women looked for work in the city's dives and cheap amusements. An alarmed Baldwin made a public plea for contributions to the Travelers' Aid. But more than half of her original budget had come from eastern sources, and most local pledges had been promised for the exposition period only. Seeking to convince Portland that a solid program of protective vice policing was an ongoing necessity, Baldwin decided to make a first-hand study of the manner in which other cities handled the "girl problem." With a letter of introduction from Mayor Lane, she left in late 1905 on a 13,000-mile self-funded tour, during which she met with a variety of urban officials and social workers across the nation. 13

Excited by her findings, the traveling Baldwin sent Lane an enthusiastic letter which hinted at a much broader vice-preventive campaign for the Rose City. When she returned home in January 1906, however, the protective worker learned that Portland's Travelers' Aid was in danger of dissolution. Despite the ecumenical optimism of board members 1 ike Rabbi Stephen $S$. Wise, the inter-faith panel found itself unwilling to continue its work. Squabbling and without funds, the board declared its mission accomplished 
and dissolved itself after voting Baldwin an extra week's salary. The crisis passed, however, when the YWCA agreed to assume sole sponsorship. Under the motto "Protection for Girlhood," the agency reconstituted itself in early February as the Travelers' Aid Department of the YWCA and named Baldwin as its director. 14

The new agency supplemented vice-investigative work by coordinating assistance among public and private institutions to help women and girls who were in "morally dangerous" situations. Baldwin's handling of one young unmarried pregnant woman exemplified this process. First, she contacted Portland's Associated Charities, which provided food and rent money. Then, she called the Visiting Nurse Association, which summoned a physician to examine the girl. When the doctor determined that the young woman had tuberculosis and would need a Caesarean section, Baldwin arranged her admittance to Good Samaritan Hospital and asked Associated Charities to furnish baby clothes. In the meantime, she took the girl to the District Attorney to swear out a complaint against the man responsible for her pregnancy. After the birth, the mother and child were transferred to the Florence crittenton Home. When the young woman developed complications from the birth, Baldwin had her moved to the county hospital for treatment. 15

Baldwin stretched her hard-won budget by utilizing charitable facilities available in the community and by 
arranging for low-cost or gratis medical and transportation services. She gradually won a reputation for frugal, yet fair-minded competence. Prominent salmon packer James $\mathbf{W}$. Cook, for example, augmented Baldwin's 1906 budget with a $\$ 500 \mathrm{gift}$, and reported that her work was "the most practical and far-reaching social effort for girls that he had ever seen." In April 1906, the Chamber of Commerce asked Baldwin to disburse its $\$ 4,750$ relief fund for the arriving victims of San Francisco's earthquake. Because the disaster to the south absorbed so many of the donations usually made to Travelers' Aid, contributions to her own budget totalled only $\$ 1470$ for the year. 16

Despite continued solicitation, the Travelers' Aid budget could not keep up with the demands made upon it. Besides Baldwin's salary, the organization now supported a full-time assistant and an employment secretary. Matters became worse as Portland experienced the repercussions of the financial panic of 1907. As unemployment in the low-wage sector jumped, the agency's employment service could find positions for only one third of the young women who applied. Baldwin feared the remainder would be forced to seek "easy money" in crime and prostitution. Indeed, the sexual vice investigations she termed "police cases" more than doubled in 1907.17

Portland's vice element quickly learned that Baldwin "vigorously" prosecuted both men and women "preying upon 
innocent girls." If the protective worker thought a fine or jail term too light, she published the offender's name and occupation in the newspapers. In one six-month period, Baldwin successfully guided eight sexual vice cases through the courts, each resulting in a heavy fine or jail time. The Juvenile and Municipal Courts, District Attorney, and the United States Attorney applauded her efforts. The city's patrolmen, moreover, called on her at all hours of the day or night to handle "the cases where a woman was needed." Acting on tips, Baldwin described herself going "alone, times without number, into the saloons and dives" to retrieve endangered underage females. Believing that women policing agents could be as effective as men, in late 1907, Baldwin presented herself as a de facto member of the police department and began lobbying the city government to pay for her vice crime work. 18

Before taking her campaign to city officials, Baldwin compiled a lengthy report of her work of the past three years, and placed special emphasis on her policing role. She then distributed copies to Mayor Lane, the police board, and the ways and means committee of the city council. The document asserted that Portland needed women officers and that such protection workers had performed vice-policing tasks to the satisfaction of city officials. The municipality, Baldwin explained, had "enjoyed the services of a diligent officer without the cost of one cent." After 
reiterating her ability to perform miracles with scanty funds, the Travelers' Aid director observed that the city had earmarked over $\$ 6,000$ of its proposed 1908 budget for the dog pound. Unblinkingly, she requested "half that sum" to help prevent vice crime among "the growing girlhood of the city." The police department appropriation, she noted, was almost $\$ 220,000$. "Will you," she asked, "place $\$ 3,000$ of it to be used for the girls of Portland?"19

Baldwin's ploy had the desired effect. On December 23, 1907, the city ways and means committee recommended appropriating $\$ 3,000$ to fund civil service positions for three females in the police department, although the council's police committee later reduced the number of women to two. Within six weeks, two ordinances which specifically authorized the appointment and remuneration of "one female detective and one female clerk, to perform police service" were readied for a final city council vote. 20

The council police committee proposed a $\$ 150$ per month salary for the detective's position, normally the pay of a captain. Since the sum was was twice Baldwin's Travelers' Aid stipend, and $\$ 35$ more than that of a male detective, she sought to quell potential criticism of the disparity by lobbying Lane and the councilmen a few days before the vote. "You, as men," she prodded, "know what perils confront the young girl who is obliged to be out in the world to earn her living." The woman who filled the detective's position, 
Baldwin argued, "must be a trained worker, and [would be] entitled to the salary named." Her own efforts of the past three years, she reminded them; had "accomplished more than could have possibly been done by a dozen regular patrolmen." Appealing simultaneously to their sense of civic pride and paternalism, Baldwin volunteered that "other cities," had written for information about her work. If Portland took the initiative in funding her vice policing program, she asserted, it would "be known from east to west as the city which believe[d] in protecting and cherishing pure, sweet, young womanhood." 21

Following Baldwin's well-crafted appeal, the council voted unanimous approval of the women's police ordinances. A 95 percent score on the Portland civil service board's "female detective" qualifying exam clinched her appointment. After posting the $\$ 1,000$ security bond required of police department candidates, the enforcement agent-elect took her oath of office at city hall on April 1, 1908. With an official title of Superintendent of the Women's Auxiliary to the Police Department for the Protection of Girls, she began duty as the nation's first municipally-paid policewoman. 22

Harry Lane, one of Baldwin's earliest mentors, represented a new type of Portland mayor. A respected local physician, Lane entered the 1905 mayoralty race because of concern with health and vice issues. Although grandson of an Oregon governor, and son of a congressman, Dr. Lane was 
not a professional politician, but a "professional" who brought the cult of expertise to government. Elected by a coalition of reform Democrats and Republicans, he represented the "social hygiene" impulse of Progressive era politics. While concerned with concrete hygiene issues such as meat and milk inspection, sanitation, and public health, reformers like Lane addressed other forms of urban pathology by adapting medicine-inspired "preventive" philosophy to the "body politic." 23

As a champion of public hygiene, Lane wanted to make Portland "America's healthiest city." Acting without gender prejudice, he appointed Dr. Esther Pohl as the first female head of a health department in the United states and Sarah Evans as the first woman market inspector. Having pursued post-graduate medical studies in Europe at a time when the Continent pioneered new attitudes about the dangers of venereal infection, Lane saw sexual vice as a public health problem. When the American Medical Association held its 1905 convention in Portland, Lane addressed the delegates as both mayor and physician. A recent change in attitude had shaken the organization. Six years earlier, the AMA had censored as "filth" a paper on "the hygiene of the sexual act." By 1905, however, many such "urology" lectures appeared in its national convention program. 24

Medical alarm centered on the prevalence of so-called "innocent infections." New evidence from Europe showed that 
non-symptomatic venereal diseases still might be infectious. Dr. Prince Morrow of New York, who led the drive for awareness among American physicians, estimated that up to sixty percent of mature males had at one time or another contracted syphilis or gonorrhea. If passed on to unsuspecting wives, these silent infections caused blindness in newborns, and sterility, uterine inflammations, or full-blown venereal disease in women. Such tragic consequences, asserted Morrow, could be traced back to the "irregular sexual commerce known as prostitution." Preventive medical practice sought to eliminate the source of disease. Lane, therefore, justified the abolition of Portland's vice district as a public health measure tied to overall municipal reform. 25

Early in his first term, inherited political conditions dampened the new mayor's zealous vice crusade. Lane discovered that reform in the mayor's office did not induce instant change in police or courts, or alter ingrained public attitudes about the waterfront vice district. It was an open secret that many wealthy Portlanders reaped high rents from buildings housing "disreputable businesses," and influenced selected officials to minimize prosecutions. Indeed, a number of the "clubwomen" who supported Baldwin's Travelers' Aid work were the wives and daughters of these landlords. Salmon canner J. W. Cook, who gave Baldwin $\$ 500$ in 1906, was himself an owner of North End properties. Lane 
repeatedly found himself frustrated in attempts to combat prostitution. Although ordering an increase in raids, convictions habitually eluded him. Defiant vice proprietors "seemed to think that the ordinances have been suspended," reported Captain Philip Bruin, the mayor's hand-picked police inspector. Suspecting graft, the mayor fired the entire detective force. But problems in the courts continued to dog his efforts. Too often, even with "evidence that would convince any intelligent man," confided Bruin, Lane's replacement officers saw their cases "come to nothing." The inspector remarked that he had made "many personal enemies... amongst the prominent citizens" merely by "applying the law." 26

While Lane's efforts stalled at every turn, Baldwin's prosecutions and courtroom monitoring often yielded meaningful fines and convictions. The women's police superintendent, in her own words, possessed an "Irish" temperament which "relished a good fight." Co-workers soon realized that "she couldn't be bought, she couldn't be influenced, and she couldn't be intimidated." Baldwin's focus on the female victims of vice, and tenacious pursuit of those "preying on innocent girls" brought frequent approval from the mayor's office and the more reform-minded press. 27

The new female detective's program of preventive policing clearly meshed with Lane's social hygiene 
priorities. It also represented what one historian of police professionalism has described as "a distinct departure from the traditional police role." Baldwin added a new dimension to what was formerly a "remedial" profession. Instead of urging male officials to "use the police power" to protect women, as reform predecessors had, Portland's lead protective worker promoted the use of female agents to perform such duties. Social hygiene theory called for a purification of urban society to make it "safe" for women to enter the public sphere. Baldwin pre-empted the "male" prerogative in the field of policing. She argued that unaddressed concerns for the city's young women called for the immediate placement of a "mother-heart" into Portland law enforcement. Mayor Lane's inability to combat vice through the existing police structure compounded the challenge. In Baldwin's words, "a woman was needed" to rectify the status quo. ${ }^{28}$

In many ways, Lola Baldwin may be described as a "social feminist." She embodied a compromise between the occupationally-restrictive Victorian past and the new world of women's opportunity. For example, Baldwin supported woman suffrage because she hoped to give reformers like herself control over legislation designed to protect their own gender. Yet, the superintendent of the women's police auxiliary exhibited a greater interest in these reform goals than the vote itself. Baldwin's agenda evolved from 
traditional notions of gender difference, not concepts of sexual equality. She followed the example of reformer Jane Addams, who successfully translated the role of female purifier of the home into the arena of public service. As William L. O'Neill has observed, such a rationale allowed women like Baldwin to "retain their traditional image as domestic beings, while at the same time transcending it." By adopting a "nurturing" posture, Portland's first policewoman broke down objections to her inclusion in the formerly male bastion of police work. 29

Social hygienists like Harry Lane promoted women such as Baldwin to official capacities because they viewed them as political and societal "housekeepers." For the most part, Portland's "leisure class" club women shared this social perspective. Pet interests, such as juvenile delinquency, alcohol abuse, women's safety, and censorship frequently coincided with the policewoman's agenda. Like many of her cohorts, Baldwin struggled to codify traditional moral values within modern "scientific" reforms. Although she embraced the progressive reformers' use of statistics to show social causes of degradation, for example, she peppered her analyses with old-fashioned moralizing. Enmeshed within the tensions and ambiguities of the Progressive era, Baldwin had difficulty in acknowledging rapid popular acceptance of changes in social mores. Much of this cultural gap centered on altered work force demographics and the rise of a tangential "democratic" amusement sector. 30 
THE MENACE OF RAGTIME PORTLAND

Baldwin asked to retain her office in the YWCA once the city hired her. Experience had shown that few young women or girls would report problems if they had to go to the regular station house. With the same logic, the new female detective refused to dress herself or assistants in uniform. Fearing to frighten those they sought to help, they kept badges pinned inside jackets, or tucked away in purses. This "plain-clothes" tradition endured among Portland policewomen until the 1970s. Early in the twentieth century, the policewomen's clientele included many working-class girls who lived in rooming houses, away for the first time from the protective influence of families. Female law enforcement professionals like Baldwin hoped to extend a "mother-heart" into municipal policing to substitute for this absent familial control. Consequently, most aspects of young working women's lives, including their employment conditions, lodging, health, and after-hours amusements came under the scrutiny of the women police. 1

A typical case resembled that of a young woman reported to Baldwin by Dr. Esther Pohl, the city's health officer. Pohl described her as a "mentally and physically weak" shop 
girl who read "trashy novels," and imagined herself a fictional heroine. The young woman lived in a rooming house which the doctor thought "unfit, as she would be an easy prey to men." Prevailing social science notions anticipated such predisposition to moral weakness among the working class. Consequently, Baldwin portrayed her police role as one which sought to prevent sexual immorality and exploitation through "timely" investigation, aid, or warning. In their first month of municipal policing, she and her assistant Lucy Sargent inspected moral conditions in ten rooming houses, located four of five girls reported as missing, and checked out thirty-two after-work amusements. The two scoured the newspapers for fake or questionable employment ads and arranged temporary food, rent, and medical aid for a number of jobless clients. In addition, they gathered evidence in three sexual procurement investigations involving underage females. 2

Policing of amusements became one of Baldwin's weightiest chores. By the turn of the century, many young female laborers believed they had earned the right to after-work diversions long allowed to their male counterparts. Boardinghouse girls, especially, were not tied down to the housekeeping chores still expected of home-living work force sisters. Regulated hours of production and independent status gave them the benefit of several hours of free time in the evenings. Males 
traditionally had filled this time with the same-sex camaraderie of the saloon. Young women, however, were not attracted to such sedentary recreation. Their preference for dancing and light-hearted excursions and entertainment helped spur a shift in the makeup of urban working-class distractions. As Kathy Peiss has shown, commercial dance halls, movie theaters, skating rinks, and amusement parks expanded to meet a low-end consumer demand for mixed-gender pastimes. Middle-class reformers such as Baldwin looked on in dismay as the lower classes redefined public inter-sex behavior. 3

As a professional purity crusader, Baldwin initially saw the emerging commercial amusements as symbols of a spreading breakdown of social and familial control within the working classes. However, events such as the 1905 Lewis and Clark Exposition legitimized commercial amusement attendance for a wider segment of the population. After the extravaganza ended, local resorts scrambled to perpetuate the excitement of its exotic midway. "The Oaks" amusement park on the city's southern boundary expanded, and lofty Council crest was soon crowned by a roller coaster, an "observatory" atop its water tower, and a new dance hall. In the downtown area, dance halls, restaurants, nickelodeon movie houses, "family" vaudeville theaters, and similar businesses competed for an unprecedented mix of both working and middle-class patrons. This growing and prosperous 
commercialized pleasure sector provided policewomen and other reformers with a hydra-headed target. 4

As the attraction of consumer amusements began to embrace the middle class, so did fears that lower-class immorality would contaminate the daughters of the upper strata. Commercial pleasure resorts attracted young people to a mixed-class, mixed-sex realm unknown in victorian times. The places that Baldwin lumped together as "moral pitfalls" provided almost unrestricted inter-class social congress. In a typical "worst case" scenario, a naive middle-class girl, exposed to the "base passions" of the lower classes at a dance hall, might be plied with alcohol, then whisked away to a rooming house, the back seat of a hired automobile, or the dark arbors of one of the public parks. Once sexually "ruined," reformers worried, such young women were ripe candidates for disease, unwed pregnancy, or prostitution. 5

Baldwin's struggle with the problems posed by the mixed-class dance hall exemplified the post-Victorian reform dilemma. Having already lost the battle to confine the sexes, races, and classes to their nineteenth-century amusement spheres, reformers sought to define the terms of the new status quo. Their starting place was less than encouraging. In 1908, one Portland judge attested that most delinquent girls who came before him named some dance hall as the place they met those who led them astray. Public 
dances admitted anyone, and drunks, known prostitutes, pimps, and other "persons of adventuresome character" mixed freely with more innocent young people. Low-wage working girls from the boardinghouses were attracted to the dance halls, as one told Baldwin, because they were "lonesome, and there was no other place for a girl to go." Their well-heeled sisters attended for the fun and adventure of it. Attractive young women, moreover, regardless of their financial circumstances, were always admitted free and "used as bait to draw trade." 6

From the beginning, Baldwin ranked the public dances as some of the worst pitfalls in town for unwary young girls. The reputations of these establishments carried a stigma from the nineteenth century, when they had been resorts for single working men who paid for dances and other favors from professional prostitutes hired by the management. Although female dancing partners generally were "respectable" women by the turn of the century, certain elements lingered. Nearby saloons offered cheap drinks to dance patrons and sometimes harbored local prostitutes who mingled with the dance crowd. Portland's Maple Pavilion, for example, stood on the same block as a saloon, and patrons drifted freely from one to the other. Merrill's Hall, at 7 th and Oak, was located on the second floor above another barroom, which was directly accessible by a back stairway. Baldwin personally observed under-age girls being served beer there, and she 
herself, a middle-aged matron, received unwelcome advances from a drunken man on the stairway. 7

The style of music favored in the dance halls explained much of the negative response elicited from officials. After the turn of the century, "ragtime" and jazz rhythms popularized by black musicians in the brothels and dives of Mississippi River towns migrated northward. In the industrial cities, white working-class youth soon were attracted to its raucous vitality as an antidote to the dreary monotony of factory jobs. The music's beat, as one patron put it, "demanded a physical response." Inventive dances which accompanied the new tunes featured an emphasis on close contact and "suggestive motions of the pelvic portions of the body." Many of these so-called "tough dances" were blatantly imitative of human or animal sexual activity. It took little imagination to see the point of dances with names like "hug me close," "the shiver," the "hump-back rag," the "lover's walk," the "dip," the "slide over the wave," the "rough dance," the "turkey trot," the "grizzly bear," or the "angle-worm wiggle." 8

The rapid popularity of sexually overt dances shocked elders reared on the chaste waltz. Even the waltz was perverted when dance hall managers turned lights so low that partners had to grope for each other in the dark. Reigning over all was the principal fear that the "ersatz sex" of the dance floor would lead to the real thing. Adult concern over 
this risk of moral ruin was intensified by the fact that the girls who attended were so young. By 1910, a survey by a New York reform group found that the majority of female patrons were under twenty years of age, with some as young as twelve or thirteen. Whether poorly paid, lonely, or straining against the control of middle-class homes, the young of both sexes were seeking release in the energy and anonymity of the new dance palaces. 9

Portland's dance halls were, at best, unruly. Baldwin often observed drinking, fighting, and even open soliciting. Unlike their nineteenth-century counterparts, many of the city's new commercial dance halls located outside the vice district. Otherwise-quiet residential areas like sellwood, Lents, Mt. Scott, St. Johns, and Portland Heights all boasted such places by the late 1900s. When some dances ran all night, nearby residents complained to the police. Yet, there seemed little effort by city officials to remedy the situation. Baldwin soon concluded that these establishments were vital to those, at all levels, who benefited from the sub rosa largesse of the "liquor interests." Thus, even the police chief's Sunday closing recommendation was ignored. In June 1908, after several fruitless inquiries to the city license committee, the detective took matters in her own hands. By state law, she discovered, all dance halls and like amusements had to be licensed and regulated. "There is not a question," she reported, "but that every poolroom, 
bowling alley, billiard room and dance hall are running in open violation of the oregon statutes."10

Harry Lane's successor, Joseph Simon, hoped to close the dance halls completely. Baldwin agreed philosophically, but her experience had shown such action to be practically impossible. As early as June 1908, the superintendent of the women's auxiliary had taken a second-best "clean up, not close up" position and advocated stringent regulatory licensing. After Simon replaced Lane, night life interests on the city council tried to discredit Baldwin because of her growing influence in police matters. Portraying her as a "Lane holdover," councilmen (and future mayors) Allan G. Rushlight and George L. Baker sought to drive a wedge between the woman detective and the new city executive. Baker showed Simon an official letter in which Baldwin allegedly "commended" the Casino Dance Hall. In complaining that sunday dances had not ceased as ordered, the policewoman had graciously worded her protest in a way that could be read as praise for previous cooperation. The flap was over in a few days, but Baldwin's adversaries won a minor point when Police Chief Cox reprimanded her for the letter's tone and for issuing press statements without his permission. 11

Baldwin received validation for her stand on regulation when the daily oregonian addressed the subject of commercial amusements in 1910. The editors acknowledged that leisure 
pursuits were an "essential factor in life" and suggested that dances provided all the recreation "a certain class of people" could afford. Yet, they also insisted, Portland's "Christian capitalists" had a duty to regulate dance halls into "clean" (though not less profitable) resorts. Soon afterward, the city passed its first dance ordinance.

Baldwin approved of clauses which banned specific "immoral dances," forbade alcohol sale or use, and required separate dressing rooms for males and females. But in setting closing time at midnight, and minimum admittance age at eighteen, the ordinance fell short of the policewoman's hopes. Baldwin insisted that eleven o'clock closings were more preferable and that no one under twenty-one be allowed admission. Girls under that age, she reasoned, were still too young to protect themselves from morally dangerous situations. Without more comprehensive regulation, Baldwin contended, Portland's dance halls remained mere "recruiting stations for prostitution." 12

The growing popularity of recreational dancing throughout Portland made the new ordinance difficult to enforce. The Council Crest Dance Pavilion in Portland Heights became a focal point of the controversy. In mid-1910, wealthy businessmen-residents complained that overflowing dance-bound streetcars prevented them from getting home at night. Some had protested to the city about the building of the dance hall the previous year, calling it 
an "outrage upon the home life of the district." Feelings ran so high that one furious resident purposely derailed an overcrowded car that failed to stop for him. The Pavilion manager argued in vain that Halley's Comet, not the dance, had attracted the crowds to his grounds. Once elite citizens had suffered the spillover effects of public dancing, however, the city council passed an absolute ban on such amusements. At year end, a much-surprised Baldwin reported that all public dances had been put out of business. 13

Despite Baldwin's sense of accomplishment, dance palace prohibition proved transparent and temporary. Some dances, sporting names like the "Minuet Club," the "University Park Club," the "Carnival Club," and the "Bachelor Buttons Club" reopened as unregulated private venues which charged "dues" at the door. As soon as the furor over Council crest died down, the city began to re-license the public dance halls which agreed to obey the 1910 ordinance. Even fund-raising dances by fraternal organizations, benevolent societies, and church groups began to draw large crowds. Baldwin's police log noted deteriorating patron behavior at public halls, where "the tendency of quite a few was to rag." Prompted by such reports, the city council ordered another wholesale closure in 1912. By then, however, Baldwin and others recognized that recreational dancing had become ingrained at all class levels. With input from Portland's branch of the National Playground Association, a committee of concerned 
local citizens, and the city license board, the superintendent of the women's police section drafted an a11-encompassing dance ordinance. 14

Approved in August 1913, the new code covered al1 dances, both public and private, and regulated everything from licensing to the hiring of a special dance inspector. One of the flaws of the old ordinance had been its "by name" prohibitions of certain dance steps, which necessitated frequent updates. The law now simply described the only permitted dance position as the time-honored waltz. Above a11, partners were admonished to "keep their bodies and faces free from each other." All attendees were required to pay admission. Those under eighteen had to leave by nine p.m., unless accompanied by parent or guardian. The dance floor was to be "brightly lighted at all times" and musicians could not exceed a prescribed tempo. This "progressive" code became a model for reform in other cities, and according to Baldwin, formed the basis for a dance code drafted by New York City in 1922.15

The 1913 Portland dance ordinance represented an attempt by Progressive era reformers to "uplift" an amusement with roots in the lower classes and make it amenable to middle-class social mores. By championing the waltz position, it codified victorian recreational norms in a "modern" commercial amusement institution. Universal entry charges eliminated the free admission of young females as 
"bait" to attract business but also discouraged working girls from attending. The code further reduced the participation of boardinghouse residents by setting a nine $o^{\prime}$ clock curfew for those under eighteen without adult escorts. Kathy Peiss has argued that such measures were not merely protective, but were designed to curtail independent working girls' relative social freedom, which "resonated uncomfortably" with the middle-class. From another perspective, Portland's dance hall ordinances represented a civic attempt to codify what Lary May has described as the private, middle-class "sexual order of the past" and make it relevant to the modern era. 16

Vaudeville theater exemplified another amusement which altered its "low" birthright during the Ragtime Era. Originally performed for nineteenth-century male saloon audiences appreciative of its smutty content, its form changed as "circuit" managers sought "family" audiences by cleaning up their bills and booking acts into legitimate theaters. Although impressarios toned down sexuality and language to attract mixed crowds, a certain "naughtiness" prevailed. In the same way the "new" dance hall embraced the music of the bordello to negate the stuffiness of the victorian parlor, "refined" vaudeville eschewed the moralizing ballad for the "ragtime ditty." Headliners were touted as warm, "friendly entertainers," who guided audiences through fantasies of the new consumerism, 
liberating people from Victorian constraints. As Lewis Erenberg has observed, rapport between theater-goers and performers exhibited an informal, often sexual banter that bristled the neck hairs of reformers. 17

Portland's early policewomen were responsible for overseeing the moral content of acts which played the city's vaudeville theaters and concert halls. Perhaps the greatest challenge arose over a celebrated confrontation with the famed William Morris Circuit star, Sophie Tucker. In November 1910, the buxom twenty-three year old Tucker brought her flashy song-and-dance act to Portland's Pantages theater for a week. After the first show, an anonymous patron complained to Baldwin that the exhibition "grossly disturbed the public peace, and...outraged public decency." Notebook in hand, the policewoman attended the next performance. After scrutinizing the costumes, 1yrics, and dance motions of the ample-bosomed songstress, Baldwin decided that two routines, "The Grizzly Bear," and "The Angle-worm Wiggle," were "particularly objectionable." The superintendent quickly swore out a warrant for the singer's arrest on city indecency charges. 18

After immediately paying Tucker's $\$ 50$ bail, the manager of the Pantages convinced the police court to postpone its preliminary hearing until after the engagement ended. When the theater operator invited Police Chief Cox to review the performance, cox found nothing wrong with the act and 
allowed it to continue. Infuriated, Baldwin railed against Tucker, calling her "a woman from the Barbary Coast of San Francisco," a period euphemism for "prostitute." The policewoman swore out a second warrant, this time on state indecency charges. Meanwhile, she described the singer's act to Mayor Simon and persuaded him to order Cox to halt the show. But the city's top protective worker reckoned without the feisty Tucker. Incensed at Baldwin's public questioning of her character, the singer threatened to sue the city for defamation and "fight to the finish" to prove that she was not immoral and had "done nothing wrong."19

"I am earning an honest living," Tucker told the Oregonian, "and am sending money home to my folks." The assertion she was from the Barbary Coast was "untrue," the Connecticut-born performer continued, "and I cannot understand why Mrs. Baldwin should say these falsehoods about me." Fending off a charge that she had ridiculed the policewoman from the stage after the first warrant was waived, Tucker said she had simply asked her audience if it thought her act was "very immoral" or not. "I am affiliated with too many charitable associations," the singer remarked, "to condemn anyone who is trying to do good. I am not that kind of a woman," she reiterated, "and I am sorry Mrs. Baldwin thinks so badly of me." 20

The next day, city officials convened a hasty conference among Tucker, her attorney, Baldwin, and state 
and local legal authorities. Each side agreed to drop charges against the other. Baldwin grudgingly provided an apology for the matter, saying she had "no personal animosity toward Miss Tucker." The policewoman defended her actions, however, by observing that it was her official duty "to know what is going on at the theaters where young people are attending in great numbers." The singer, in turn, expressed delight that "the whole business had been taken out of the courts" and that she could resume her tour. Although Baldwin forfeited the case, she did not long conceal her personal sense of victory at, temporarily at least, closing down "the last of the red-hot Mamas." In January, 1911, she reported to Mayor Simon that she had read that Tucker had been "restrained from giving performances" in other cities. Furthermore, she wrote, the same musical numbers she and the mayor had censored had been "tabooed and criticized by the theatrical papers," in apparent vindication of them both. 21

The Sophie Tucker affair exhibits central cultural conflicts and contradictions of the Progressive era. On the one hand, Baldwin continued to associate vaudeville with its saloon roots. She did not make any distinction between the barroom skits at North End vice dens like "Fritz's Theatre" and the Broadway variety shows which were gaining middle-class support under her very nose. Although Tucker had agreed to "sing any song suggested, and wear street 
costume" if she could remain on the bill, Baldwin refused to back down. The policewoman objected to Tucker's general performance demeanor, which, she wrote, had but "one effect on the public mind, that of debauchery and indecency." The singer's appearance probably had much to do with such impressions. Although quite young, she had a very "matronly" body, which she decked out in tight, long-skirted, low-necked dresses, topped with big feathered hats. Tucker moved her bulk with an unexpected sensuality, and possessed a large brassy voice. Whether she intended it or not, the singer evoked a devastating parody of the sacrosanct victorian aunt. Baldwin undoubtedly viewed it that way, and placed the blame for most of the period's "trouble with the young people" on socially irreverent and mixed-audience amusements like vaudeville. 22

In sisterly irony, Tucker, like Baldwin, had created a niche for herself as a new "professional" woman. In less than a year on stage, she heralded herself as "one of the biggest attractions on the William Morris Circuit." The daughter of Jewish immigrants, she saw the reformed theatrical venue as a legitimate vocation for decent young women like herself who struggled to provide for their families. In an interview with the oregonian, Tucker spoke with pride of her 1903 graduation from Hartford's Morse Business College. She also recounted awards given her by the cities of New orleans and Indianapolis, where she sang in 
the streets to earn over $\$ 1500$ for poor children at Christmas. Tucker berated Portland's first policewoman for arbitrarily terminating her ability to support her mother, sister, and brother. Ironically, the singer's core values of salaried independence, maintenance of family, and care for the unfortunate were little different from Baldwin's. Both women were professionals who sold their expertise. What most galled moral reformers like the Portland women's policing superintendent, however, was the fact that female performers like Tucker had found a way to sell their sexuality yet still remain "respectable." 23

Portland was no backwater when it came to new types of entertainment. Early forms of the ultimate egalitarian amusement, the "movies," appeared in the city in the 1890s, when Thomas Edison's "kinetoscope" coin slot machines were installed in downtown "arcades." Within a year of their development in 1896, "Electrograph Entertainment" offered Rose City audiences large-screen motion pictures. As entrepreneurs recognized the potential of this new form of amusement, makeshift "storefronts" gave way to whole buildings specially fitted for viewing. Because films were silent, they especially attracted recent immigrants, who could enjoy an "American" experience without a language barrier. But the movies were equally fascinating to people of all classes, and therein lay a reformers' dilemma. The first example of mass entertainment, "nickel madness" soon 
infected a vast cross-section of society. The prospect of diverse strangers arbitrarily seated together in dim caverns, however, gave moral watchdogs severe fits of anxiety. 24

By 1908, Baldwin and her policewomen monitored the movies as part of their systematic investigation of all amusements. Marquees with names like the "Bijou," "Lyric," "Majestic," "Globe," and "Oh Joy" beckoned Portlanders into dark, flickering interiors to view assorted "shorts." Ubiquitous coin-operated "picture machines" stood in the odd corners of small businesses, in downtown penny arcades, and in the waiting rooms of the railroad, inter-urban street car, and ferry terminals. Reformers' problems with the films were twofold: a discomfort with moral content, and concern about the conditions in which they were shown. Following an afternoon sampling slot picture machines, the head policewoman judged that "the general atmosphere of the whole thing was against good morals." In the large-screen exhibitions, however, she usually found little objection to film content. Baldwin's main concern, as perceived in the context of her morality enforcement, was that "young girls $h[u] n g$ around the places to meet boys." 25

Although the police superintendent and her assistants lacked the time to scrutinize the moral content of all the city's film offerings, Baldwin did make her services available on specific complaints. In 1911, for example, her 
review of the "The Night Riders," an early version of novelist Thomas Dixon's Ku Klux Klan romance, The Clansman, resulted in the arrest of the manager of the Majestic Theatre. Baldwin condemned the film because it "exploited hanging, outlawry, lynching, and incendiarism." The reel was turned over to Portland's grand jury, which cut what it considered the most objectionable parts, and then allowed it to be shown. Soon thereafter, concerned women from the city's Associated Charities, Woman's Club, Council of Jewish Women, and Child Labor Commission formed an unofficial movie censorship committee to review all films before exhibition. This action relieved the policewoman of ex post facto responsibility. In 1915, the group obtained official sanction as the Municipal Board of Review, which functioned until its repeal in 1970.26

By 1913, 70 percent of a sample of 2618 Portland grammar school students reported going to movies once a week or more, 64 percent of this number attending in the evenings. A new nine p.m. curfew for unaccompanied minors had taken effect in May 1912. Despite this action, six months later, a Social Hygiene Society worker found 1215 youth under that age in violation during one two-evening survey. The Oregon Congress of Mothers blamed the theaters for allowing unaccompanied children in their establishments after curfew, and blasted police authorities for not assigning more patrolmen to enforce the ordinance. Baldwin 
philosophically disagreed with the organization. It was not more police that were needed, but more attention paid to children in the home. Unchaperoned movie attendance, in violation of curfew, she reasoned, was just another symptom of a decline in the influence of families at all class levels over their children. 27

As the censorship movement sought to uplift the moral content of films by the $1910 \mathrm{~s}$, it recognized that consumerism, not traditional producer values, dominated movie subject matter. Nevertheless, some reformers tried to turn the novel medium to moral uses. Baldwin applauded the Council of Jewish Women, for example, when it rented the Globe Theater in 1913 to show "The Evils of the Dance Hall," a "moral warning" film. The policewoman, however, continued to record cases of young girls loitering in lobbies, and instances of boys who occasionally took sexual advantage of them. To her dismay, movie theaters rapidly became part of a modern youth culture in which all sexes and classes mingled without stigma. To her credit, despite her misgivings about the theater environment, Baldwin saw the potential for mass communication in the film houses and arranged for "lantern slides" of missing girls to be shown during intermission. 28

In the years preceding World war I, dance halls, vaudeville theaters, and movies were the temples of an emerging American popular culture of mixed-sex, mixed-class 
leisure and consumption. In large part, reformers like Baldwin blamed the decline of family control over young people for the rise in what they perceived as immorality. In fact, they were witnesses to one of the greatest shifts in social mores in the nation's history. The recreation demands of a new class of independent young working men and women caused change in the character of certain amusements. Reformers had a difficult time realizing that the new leisure pursuits conformed to the needs of a less restrictive modern society. Instead, they responded to their own persistent nineteenth-century stereotypes of city-debauched young women by enacting repressive regulations aimed at recreating the old social order. An uneasiness with change, a fear, as reformer clifford Roe expressed it, that "an America commercialized ha[d] commercialized its daughters," permeated much of Progressive era social effort. Policewoman Baldwin's legal struggle against the commodification of the female sex, from its mildest to its worst forms, echoed such sentiments. 29 


\section{CHAPTER III}

\section{CONTROLLING THE FEMALE DELINQUENT}

Few justice system professionals or social workers had considered a separate theory of female delinquency before the Progressive era. Earlier reformers had assumed a basic female purity paradigm which perceived fallen women as temporary "sinful" aberrations capable of rescue. Around the turn of the century, organizations like the National Conference of Charities and Corrections, of which Baldwin was a member, began to distinguish between society's "girl problem" and "boy problem." In contrast to the general criminality ascribed to young delinquent males, purity workers viewed "uncontrolled" sexuality as the root of incorrigibility in youthful women. It was no accident that the "female delinquent" appeared concurrently with popular eugenic doctrines which linked social and sexual promiscuity to a "criminal" debasement of the Anglo-Saxon race. A girl did not actually have to engage in intercourse. Certain behaviors like immodest dress, adopting male attire, using foul language, smoking, drinking, having bad companions, or associating with other races all could label her as sexually delinquent. 1 
Some delinquent girls, of course, literally were sex offenders. More often, they merely offended their sex, since their crime of "precocious sexuality" rebuked traditional purity standards which those like Baldwin struggled to preserve. Increasingly, as reformers collected data on this new quasi-criminal "deviant" sexuality, they effected legal measures to prevent, control, or contain its proliferation. In 1905, Baldwin helped organize Portland's Juvenile Court, one closely modeled on Judge Ben Lindsey's experiment in Denver, Colorado. Under the aegis of social hygiene pioneer Governor George Chamberlain, Oregon's legislature passed a comprehensive juvenile "treatment and control act" two years later. In 1913, Baldwin played a major role in convincing the state to build a separate "industrial school" for delinquent girls near salem. ${ }^{2}$

Shortly after the enactment of the 1907 state juvenile control act, Baldwin criticized Portland for its lack of a youth detention center. The regular jail offered no help to the sort of girl offenders the policewoman dealt with on a daily basis. Her logs, for example, told the story of "Minnie," a young woman frequently arrested for vagrancy and often found to be venereally diseased. "We have tried in every way to help this girl to a decent life," Baldwin confessed, "and having failed, the good of the community demands that she be kept in custody." The detective's membership in the National Conference of Charities and 
Corrections kept her abreast of the latest thinking on the "girl problem." When the organization held its northwest regional meeting in Portland in 1908, Baldwin helped arrange a telling program which highlighted topics such as the juvenile court, female reformatories, and, as a distinct subject, "delinquent gir1s." 3

The very idea of female delinquency, and therefore culpability, chipped away at the nineteenth-century notion that men were automatically guilty in sex-related prosecutions. Baldwin's case files clearly registered this transition. In late 1908, a man convicted and jailed by the Juvenile Court for "contributing to the delinquency of a minor" petitioned Governor George Chamberlain for relief. When Chamberlain asked for the policewoman's input, she advised the governor to parole the petitioner for reasons of good conduct and the destitute condition of his dependents. In her judgement, Baldwin added, the girl involved was of "habitual loose character" and contrary to the Juvenile Court's opinion, probably at fault. Chamberlain followed her recommendation. When released, the man called on Baldwin, who provided him with a letter of introduction to prospective employers. 4

A similar case involved a streetcar conductor arrested for having sex with a minor. Upon investigation, Baldwin found that the man had a "good family, and his employer spoke highly of him." The girl, on the other hand, spent 
hours loitering in streetcar waiting rooms, and was previously reported to the policewoman for being "intimate with a middle-sized Greek." After conferring with Baldwin and other police officials, the Juvenile Court dismissed the case. Since the accused carman was the third arrested within ten days on similar charges, however, the judge warned the streetcar companies to keep their men from conducting unnecessary conversations with females. He then declared the girl a "mentally defective" ward of the court, and placed her in the Catholic-run House of the Good Shepherd. This action mirrored then-current medical notions that sexually delinquent girls could not control their base instincts because they were "feeble-minded." Under this device, Progressive era judges placed numerous delinquent females under "indeterminate" or even permanent custodial care. 5 In 1912, Portland's Vice Commission found that over 70 percent of its sample of women morals offenders were "native born." Despite such data, reformers continually associated immorality and venereal disease with "non-white" immigrants from southern and eastern Europe. Many purity workers believed that delinquent "American" girls had been debauched by recently-arrived foreigners or the country's existing racial minorities. Progressive-era notions of eugenic science painted racial and ethnic outsiders as genetically inferior to white Anglo-Saxons. Like "lower animals," their sexual instincts were thought to be more acute, more 
depraved, and less controllable. Prevailing middle-class distrust of ethnics became more intense when contact with young white women was threatened. 6

Numerous violations of Portland's "color line" dotted Baldwin's police records. An "American" girl, whose mother had offended the status quo by marrying a Chinese herbalist, was reported as immoral for "associating with Chinamen." An anonymous letter complained that an Italian restaurant owner was recruiting "white women or girls...for immoral purposes." The policewoman characterized one client as "very dissolute" for socializing with "Greeks, Chinese, Japs, and anyone." She took another into custody for being "intimate with a Chinaman." A half-dozen entries documented the surveillance of a "good looking Greek" who ran a bootblack stand at Third and Alder. The man came under suspicion because he was "very familiar with young white girls" and sometimes shined their shoes for free. Greek restaurants, in general, were suspected of luring "American women" into prostitution. The proprietor of the Omaha saloon at Sixteenth and Pettygrove reportedly "enticed" young white women into a room frequented by "Poles, Russians, and Slavs." The most intense scrutiny, however, was reserved for the ultimate cultural taboo, illicit relations between black and white. 7

Portland's 2,500 African-Americans represented only one percent of its population in the 1910 's. Nationally, racial 
tensions had resulted in bloody violence against blacks. A particularly virulent "race riot" in springfield, Illinois, in 1908 resulted in the formation of the National Association for the Advancement of Colored People (NAACP). In 1912, black boxer Jack Johnson was convicted for the seduction of a white woman in a "white slave" case that aroused national attention. Some whites believed the Johnson affair demonstrated that blacks were sexualiy "out of control." Portland became very sensitive to what its NAACP labelled "the sex problem of the Aryan and the African." When police raided a brothel run by "a negress" at North Fourth and Everett in 1912, detectives found that four white girls worked at the mixed-race house. The idea of white women, even prostitutes, servicing blacks caused outrage. The suspected madam was arrested and bound over to the grand jury under maximum bail. Baldwin convinced two of the white girls to testify, and the proprietess was indicted, tried, and convicted of "operating a bawdy house." The witnesses, who were held in protective custody, were released uncharged. 8

The following year, Baldwin took up a case involving several "white girls and negroes" at the st. Francis club, a private "colored" bar. A seventeen year old white girl, reportediy "from an estimable family," went to the club by taxi with an older girlfriend. After an evening of drinking, they apparently agreed to have sex with two "negroes" they 
met. The case created such a stir in the white community that the mayor asked Baldwin to keep him closely informed. The policewoman and District Attorney Walter Evans grilled the young women for four hours before they admitted to "illicit relations" and "gross indignities" with the men. Evans then obtained a warrant against the proprietor for selling liquor to the minor girl, and arrested the black sexual offenders on morals charges. The district attorney further vowed to prosecute "every person connected in any way" with the case to the full extent of the 1 aw. 9

The manner in which Baldwin and other authorities responded to sex between whites and immigrants or blacks reflected the views held by most Progressive era purity workers. Reformers like herself sought desperately to preserve traditional ethnic and racial hierarchies during a tumultuous period of urban growth and modernization. Middle-class girls who succumbed to the siren call of working-class amusements were one thing, but those who sought sexual intercourse with the "racially inferior" were another. In a time when eugenic-purity enthusiasts like Theodore Roosevelt railed against the pollution of the "superior" race, or of impending "race suicide," Baldwin and her cohorts tried to prevent further degeneration of traditional distinctions and moral standards. Convinced that their efforts were well-meaning, purity workers sought to preserve Anglo Saxon cultural hegemony as the basis for 
civilized order. Their greatest fear was that shadowy immigrants and the sons of slaves might corrupt the innocence of their daughters. 10

If young women who indulged in intercourse "got caught," they either faced the dilemma of unwed motherhood or sought illegal abortions. By the late nineteenth century, abortion had been criminalized in most states. Birth control was precluded by a battery of federal "morals" codes known as the Comstock Laws. Baldwin preached premarital sexual abstinence, yet she saw daily evidence to the contrary. Numerous references to young pregnant women filled her casebook. With the tools allowed her, the policewoman tried to salvage such clients as best she could. She committed those who were afraid to return to their own families to Portland's various homes for unwed mothers. As a matter of form, she insisted on knowing the alleged father's identity. Rather than be prosecuted for seduction, many males agreed to marriage. With the full backing of the courts, Baldwin forced some reluctant fathers to wed and then imposed legal support arrangements on them. She later joined a battle for a state law mandating such paternal support. ${ }^{11}$

Illegitimate birth or "encouraged" marriage were the only legal solutions to unwed pregnancy in early twentiethcentury Portland. An 1864 state law declared abortion practice to be manslaughter, with a prison penalty of one to fifteen years. Despite its illegality, however, the 
so-called "criminal operation" flourished. Poorer women and girls sought furtive surgeries in the back rooms of boardinghouses or trusted their luck to remedies such as "Famous Sanderson's Root Pills," which were advertised to "correct menstrual troubles." If such methods failed, some girls tried suicide, while others smothered or, more often, abandoned their unwanted babies. Abortion was a parlor secret of the upper classes as well, but they could better afford the prices of selected regular physicians who kept special after-hours appointment books. 12

Botched abortions came to Baldwin's attention most often. Physical evidence such as uterine laceration or infection nominally proved the "crime," but uncooperative victims, families, or witnesses often slowed prosecution. The superintendent reported over two dozen such instances between 1908 and 1912. One well-known abortionist served as the Italian Consul and enjoyed diplomatic immunity. Baldwin prosecuted two local physician brothers a half-dozen times without success. One middle-class mother admitted that she had procured a doctor's abortion for her daughter, but refused to give his name. Frustrated, Baldwin put more energy into preventive measures. She began to use decoys to obtain hard evidence against suspected practitioners. In one instance, she sent a young female client and a male parole officer to see a "Madame Anna" in a downtown office building. After taking $\$ 25$ from the couple, the woman gave 
them some pills to cause an abortion. In addition, as she "believed that all passionate girls should indulge themselves," she told the girl to come back for a birth control prescription. The couple's evidence snared the woman on both state and federal charges. 13

On one occasion, Baldwin directly intervened to prevent an abortion. A woman reported that her younger sister, four months pregnant by a city fireman, was planning to abort her child. The fireman had placed the girl in a local boardinghouse, where the landlady arranged for an operation to be performed the next day. The policewoman went to Municipal Judge George Cameron, who informed the fire chief of the circumstances. When the chief called the fireman in, he, Baldwin, and the girl's sister persuaded the father-to-be to admit paternity and "agree" to marriage. The chief later told Baldwin that he found out that another girl, impregnated by the same man, had undergone "an abortion which nearly killed her."14

Baldwin campaigned strenuously against newspaper advertisements for abortive medications, most of which were worthless. She answered many using false names and turned the evidence over to the federal postal inspector. Despite limited success at first, she persisted in lobbying the city's dailies to stop accepting such copy. She also asked the 1909 state legislature to prohibit the sale of "quack remedies," personally testifying to the all-male body about 
the poor "betrayed country girls and more innocent city girls" who spent their hard-earned money on fraudulent products. Lost newspaper revenues proved a sticking point with some lawmakers, however, and her idea was at first rejected. When she noted that they had passed a similar code banning the sale of male venereal disease nostrums, they conceded her point and amended the medical advertisement bill. The policewoman soon reported excellent cooperation from the newspapers and secured indictments against several people for "advertising objectionable medicines."15

Baldwin's actions concerning abortion must be viewed from the perspective of both her enforcement obligations and her personal experience. First, abortion was illegal, and she was lawfully bound to prevent or prosecute it. Second, since the 1880 's, she had worked for and supported institutional homes for unwed mothers, where young women were taught responsibility for their babies and themselves. Abortion negated the whole philosophy of such programs. She had seen firsthand the results of incompetent operations, whether testifying at a coroner's inquest for a dead teenager, or in cases where other girls had been left ill or maimed. The very idea of sexuality without responsibility, of "passionate girls" indulging themselves, was repugnant to a social hygiene position of abstinent purity. Baldwin was particularly disappointed when her own class failed to set a proper example. "Criminal practice suspected," the 
policewoman reported tersely of a prominently-named young woman with a uterine infection, "but the girl herself the only one to blame. She has not been living right."16

The problem of venereal disease among young sexually delinquent clients was a serious component of early women's policing. The viral cause of syphilis had been discovered in 1905. Two years later the "Wasserman" test became widely available to detect it. As early as 1908, Baldwin distributed Portland Social Hygiene Society venereal disease literature through her offices. Alert to its symptoms, and wary of infection, the head policewoman began to request blood tests for many of the girls who came to her attention. To protect themselves from contamination, policewomen used an antiseptic wash provided by a local druggist and handled the girls' clothing with rubber gloves and bichloride of mercury before burning them. By late 1909, Baldwin reported that venereal disease was gaining "rapid headway," and wrote that some legal way must be found to commit contagious girls to custody for the "good of the community." She reiterated the need for a secure, city-funded detention facility after two diseased girls she sent to the private Louise Home climbed out a window "five nights in a row" and had illicit relations with two young men who picked them up in an automobile. 17

The State Board of Health provided some answers to Baldwin's immediate dilemma. It agreed to pay for the blood 
tests she ordered, as well as any treatment for girls found to be diseased. At the policewoman's request, infected girls could be placed under legal quarantine by state health officials, even when remanded to private institutions. When the arsenic-based drug "Salvarsan 606" became available in 1912 as a treatment for syphilis, the state funded its use for all relevant cases handled by Baldwin's department. The superintendent still insisted, however, that a separate state or city institution was needed for venereal cases. It was unfair, she maintained, for a basically "good" unwed pregnant girl to be housed in the same institution with the likes of a diseased "ten-cent sybil."18

Even before the 1910s, the increasing availability of automobiles made Baldwin's morals policing more difficult. As early as 1909, she had distributed written requests which asked Portland's chauffeured car agencies not to take unchaperoned youth out at night. The women's protective worker had discovered that mixed parties of young people were often driven outside the city limits to "roadhouses" like the "Twelve Mile House" east of the city or the "Claremont Tavern" a few miles beyond the northwest boundary. There, drivers bought liquor or beer for their under-age customers and turned a blind eye to back-seat drinking and illicit sex on the "joy ride" back to town. Motorcycles posed a similar danger, as young men could ride girls out to the country, away from the regular roads. 
Isolated from possible help, such young women were easy prey for sexually adventurous male cyclists. To police such activities, Baldwin enlisted the aid of the Portland Motorcycle Club, which pledged to form its own patrols, and turn in riders who "abused their privileges." 19

As part of her prevention program, Baldwin began a systematic study of places or situations most likely to lead to sexual delinquency among young females. Her experience showed alcohol as the culprit in many cases of immorality. Saloons, roadhouses, taverns, and restaurants which served liquor abetted the problem. By mid-1908, Baldwin had persuaded a small minority of the liquor license board that the most effective way to protect girls from the corrupting effects of alcohol was to ban them from places where it was sold. Females who entered saloons were either prostitutes or innocents in danger of seduction, the policewoman concluded, neither one of whom should be there. 20

The idea of excluding the fair sex was an interesting compromise, given the polarized saloon/anti-saloon sentiments of the day. In much the same way that Portland suffragist Abigail Scott Duniway separated prohibition proposals from female-voter legislation, Baldwin's tactic allowed men their "alcohol rights." By this concession, she hoped to increase chances of success with the all-male city government. Until she could engineer a ban, the policewoman utilized a strategy based on Oregon's legal drinking age of 
twenty-one and its 1907 juvenile codes. The basic youth control law forbade anyone under eighteen from being in any setting where liquor was "sold, exchanged, or given away." "Age of consent" provisions made it a felony to seduce or procure females under eighteen for immoral purposes or allow them to enter any place, such as a saloon, frequented by pimps, prostitutes, or their customers. Under these acts, Baldwin initiated proceedings against several establishments notorious for under-age alcohol sales. 21

In May 1908, the head protective worker succeeded in obtaining fines against the owner and bartender of the Signal Saloon for serving beer to a minor female, even though the two tried to thwart prosecution by sending the young witness to Chicago. Nevertheless, the case was not weighty enough to convince the city of the need for a ban. By summer, however, the policewoman had discovered a more viable test case. One evening, she observed a large number of apparently under-aged females being served beer at the Club Cafe Saloon under Merrill's dance hall at Seventh and Oak. An inside stairway connected the upstairs hall to the back room of the bar, so that police patrolling the street could not see who entered. Alone, or with male companions, girls came down for beer, then returned to the dance.

Baldwin herself, a middle-aged matron, was propositioned by a drunken man on the stairway as she was leaving. The setup was just the kind of situation her proposed ordinance was designed to correct. 22 
After being arrested in the place in early August, three teen-aged girls agreed to testify against the club Cafe. Their detailed descriptions of the activities in the barroom prompted the police court to turn the matter over to a grand jury. Baldwin conveyed a transcript of the girls' testimony to the city liquor 1 icense committee. On its strength alone, they revoked the saloon's permit. In mid-september, the grand jury indicted both the proprietor and his bartender on state charges of serving minors. Armed with the transcript, the revocation, and the indictment, Baldwin confronted the city council. After a heated debate in late september, the body passed an ordinance prohibiting all females from places within the city limits which sold alcohol. Although the code disappointed Baldwin by exempting restaurants, it was, in her words, "the greatest victory we have had since we began work." 23

Despite the symbolic triumph, however, Portland's head policewoman once again discovered that an ordinance depended upon enforcement from the bench. In March 1909, Baldwin prosecuted a test case against Franzel's Saloon, only to see the saloonkeeper and three women customers fined so lightly as to have little deterrent effect. The superintendent noted in her logs that almost all the day's cases before that particular judge resulted in acquittal or nominal action. "The police officers," she wrote, "had strong evidence against many, but little credence was given them by the 
judge." The case was but one of many suspicious incidents of judicial inaction that Baldwin encountered in her career. Undaunted, she began to follow justices into their chambers whenever her cases were belittled, and demanded explanations for light sentencing. Whether her persistence was responsible or not, subsequent reports noted "not having lost a case" in Municipal court. 24

The precedent of excluding females from saloons gave Baldwin ammunition for a battle against the employment of women or girls in certain amusement venues. Shooting galleries, ball-pitching concessions, pool rooms, and bowling alleys were patronized almost exclusively by men. To attract business, they often hired pretty young female attendants. The policewoman singled out the shooting galleries as an example. In 1909, juvenile court parole officer William McLaren tipped her of unsavory moral conditions in several of them. Minor female employees worked very late, he reported, and used vulgar language, threw their arms around customers and kissed them, imitated "can-can" dancers, and otherwise carried on "in a disreputable manner." The customers, for their part, took "al1 sorts of liberties with them." In McLaren's estimation, such places were "mere blinds for houses of prostitution." Baldwin tended to agree after she toured a number of them and "was herself approached in a most questionable manner by an old gentleman." She positively confirmed the parole 
officer's allegations after one girl "testified that she had solicited men from a shooting gallery, and had a different one every night." 25

By the end of 1911, Baldwin had succeeded in preventing the hiring of minors by the shooting galleries and their ilk, but really desired a total ban on female employment in such amusements. "Almost without exception," she complained to the mayor and city council, "shooting galleries and the like are located in parts of the city adjacent to the lower class of saloons and such, and are kept open late at night." If respectable young women became employed in such establishments, she wrote, they would soon "be subjected to the severest insult and temptation." A woman of "loose moral character," Baldwin continued, would simply "solicit prostitution and make dates openly." In fact, the policewoman added, the proprietors of such places had acknowledged that their businesses could not be conducted profitably without women. This was "prima facie evidence," concluded Baldwin, "that women ought not to be employed, as they are there for the one purpose of attracting men." 26 When the Portland Vice Commission took up Baldwin's cause against the shooting galleries early in 1912, their investigation reiterated her concerns. The commission found that female gallery employees made as little as $\$ 1$ a day, forcing them to seek extra cash "on the side." It also discovered several minors who had lied about their ages to 
obtain work. One saloon patron told an undercover investigator that he had caught a venereal disease from a girl in a shooting gallery, "and she was only sixteen years old at that." Vice committeemen also found "public exhibitions of intimacy" between young white female attendants and Greek or Japanese customers "positively disgusting to all persons with a sense of decency." The commission quickly reported to city hall that the cited conditions were "amply sufficient to urge the enactment of prohibitive restrictions." Soon thereafter, a city ordinance dictated that females could no longer be employed in such amusements. 27

The idea of removing females from "the occasion of sin" was basic to much of Progressive era reform thinking. Perhaps its most striking example was the enthusiasm for separate female detention homes. Purity theory suggested that if sexual delinquents could be separated from the circumstances of temptation, they might be "re-formed" through social modeling. The goals of detention facilities for girls and young women were firmly based on the traditional icon of female domesticity. By isolating sexually tainted girls from all males, they could make "a moral recovery" with time, as if cured of an addiction. By keeping them in custody during all or most of their "dangerous" mid-teens, reformers hoped such girls would make good wives and mothers when they matured. Meanwhile, the 
"industrial home" or "farm colony" provided them with nominal schooling plus courses in general domestic skills and home agriculture. 28

Baldwin was the driving force behind oregon's reform facility for girls, commonly called the Hillcrest school. While on a deportation assignment in the east in 1912, she visited several female corrections centers, including the Bedford Hills, New York facility run by penal reformer Katherine Bement Davis, and New York City's Waverly House, overseen by social workers Maude and Stella Miner. Baldwin returned with plans and outlines which she and a committee of interested men and women submitted to the oregon legislature. After a year of hard selling by the policewoman and her supporters, the state authorized the construction of a rural "cottage" facility similar to Bedford Hills. Such "anti-institutional institutions" were the cream of Progressive era penal reform. Staffed entirely by women, their rural settings and specialized rehabilitative programs harked back to pre-industrial domestic ideals. This approach reflected the insistence of social hygienists that traditional feminine nurture was the key to societal moral regeneration. 29

Under the 1913 oregon law which created Hillcrest, a twelve-year-old could be committed until she reached majority at eighteen. Those between eighteen and twenty five could be held for a maximum of three years, although both 
categories were subject to earlier release on parole. The institution's three-woman board was charged by the legislature to give "an industrial education to the inmates, and promote their moral, mental, and physical welfare." Such training might properly have been termed "pre-industrial." In August of 1915, for example, board chairwoman Baldwin reported that the girls in residence had "cultivated and raised fifteen acres of potatoes, besides filling and seeding nearly an acre of lawn, hauling in the leaf mold from the woods." Older inmates had "dug a ditch nearly 400 feet long, threaded pipe, coupled it, and installed faucets to carry water to the poultry houses and the stable." The girls apparently thrived on this kind of outdoor activity. "The only difficulty," Baldwin remarked, was that "every girl wanted a part in it, and there was not enough ditch digging to go around." 30

As the Hillcrest regimen demonstrated, Progressive purity reformers looked back in part to an "Edenic" agrarian past, when labor spheres were less gender-defined. Penal reformers like Baldwin, who sought legitimacy in the male marketplace, may have created a self-serving experiment with their young charges. By showing men that even "defective" females could be made healthy if allowed to pursue activities falsely separated out as "male" by market-industrial culture, such women bolstered their own right to compete. As chair of the industrial school's 
advisory board, Baldwin received enthusiastic support from male contemporaries who endorsed the facility's absorption with rural producer values. Portland Mayor H. Russell Albee, for example, extolled the detention home's outdoor work as "both healthful and useful." Baldwin and her board, he wrote, were "to be congratulated on having put such a project into execution." A long-time social hygiene advocate, Albee encouraged the building of a similar female detention facility in Portland. 31

Baldwin's work among delinquents followed the period's gradual replacement of incarceration-centered policies. Much of her program was based on what women's penal reform historian Estelle B. Freedman has called "extrainstitutional methods," approaches which sought to keep young women out of the courts and jails if possible. Of 460 young female offenders the policewoman handled in 1909, for example, 64 percent were further supervised through an extra-judicial system she called "after care," while only 6 percent were given formal court-ordered parole. Baldwin had devised the "after care" idea to discourage recidivism during her Travelers' Aid tenure. Calling clients in, or visiting them herself, the police detective felt it was invaluable to learn of the home lives, job atmosphere, companions, and amusement habits of her charges. Baldwin conducted these interviews, she once wrote, not to force her views upon the girl, but to "find some middle ground upon which to stand, and encourage and help her to help herself." 32 
Advocacy of specialized homes for delinquent girls reflected Baldwin's acceptance of another Progressive penal innovation, the "anti-institutional institution." Hillcrest transcended the physical limitations of a "prison" through its cottage accommodations, parole options, outdoor work, and recreation programs. It also pressed against the boundaries of domesticity by including light industrial courses and non-traditional tasks in its rehabilitative curriculum. Built in the decade immediately preceding World War I, Hillcrest was a product of the golden age of Progressive era female penal reform. In later years, harsher notions would further criminalize the sexually delinquent girl and replace rehabilitation with forced segregation and social control. When "The Cedars," Portland's female sexual delinquency and venereal facility opened in 1918, it reflected the latter, tougher philosophy. Such shifts in attitude may be followed by chronicling Baldwin's involvement in social hygiene campaigns against prostitution and its incumbent venereal disease. 33 
CHAPTER IV

THE POLICEWOMAN AND THE PROSTITUTE

The women's police idea emerged within the context of the American social hygiene movement. Arising after 1900 , its sexual morals reform component infused older, religious-based purity concepts with a "scientific" approach to societal cleansing through preventive education and state interdiction. By the time the federal government began to embrace their doctrines during World war I, social hygienists had long abandoned reform notions which viewed prostitutes as "victims." Urban policewomen Iike Lola Baldwin played central roles in this attitudinal transition. Citing new scientific evidence on the cause, spread, and consequences of venereal disease, protective workers and their political allies couched the battle against sexual vice in medical, rather than moral or religious terms. They hoped to elicit mass rejection of two key victorian-era justifications of the brothel, the "conspiracy of silence" and the "double standard."1

The "conspiracy of silence" referred to an ingrained reticence to discuss sexual matters in more than vague or euphemistic terms. As Portland social hygienist William T. Foster warned, keeping the young in "a blessed state of 
innocence" only produced uninformed or seriously misinformed adolescents. The Rose City spawned a Social Hygiene Society in 1906. Like other such groups across the country, it began to sponsor traveling exhibits and public sex education lectures aimed at parents. Delivered by respected doctors, clergy, and social welfare workers, these talks sought to give adults the latest medical information to pass on to their children. In a careful combination of medical fact and old-fashioned morals, the lectures conveyed the horrors of venereal disease, and imbued sexual intercourse with a "spiritual" aspect which idealized continence until marriage. ${ }^{2}$

As a second goal, social hygiene societies hoped to eliminate the moral "double standard." Tradition held that "good" women should remain virgins until marriage, but men were not held to the same rule. Since the medical establishment had long indicated a physiological "need" for males to indulge in intercourse once they became sexually mature, premarital experience with prostitutes was tacitly accepted as a "social necessity." Around the turn of the twentieth century, however, new evidence suggested that venereal infections thought "cured" could be passed to innocent future wives and children. Medical opinion also began to reject the notion that males needed sex. In a dramatic turnaround, the "social necessity" of prostitution became the "social evil." Reformers preached a "single 
standard" of premarital sexual abstinence for both genders and launched a vigorous campaign against the large "commercialized" vice districts which often accompanied urban industrialization. ${ }^{3}$

When Portland hired Baldwin as its first policewoman in 1908, she faced a world forged by the double standard. Sexual vice was an entrenched part of the urban landscape. Reformers hoped that adoption of a single standard of morals eventually would eradicate prostitution. Without customers, sex as a commodity would have no market. Meanwhile the social evil combined with a rising interest in premarital sex among young people to constitute the greatest threat to the girls Baldwin had sworn to protect. Portland urologist L. W. Hyde invited the policewoman to join the Portland Social Hygiene Society in her first year on the force. Such groups formed the organizing base of a movement which, within a decade, would claim credit for the almost-total demise of the American "red light district." The nation's first policewoman participated at each step of the way. 4

At the time Baldwin began her municipal career, immigrant "white slavers" generally were believed to be at the root of the traffic in women. Federal immigration laws reflected both nativist and social hygienist fears of the damage which might be done to "American home life" by "diseased alien women." Statutes enacted in 1903 and 1907 prescribed the arrest and deportation of recent arrivals 
found to be associated with prostitution. By 1910, federal codes mandated the deportation of any foreigner who even worked in establishments where prostitutes gathered. Immigrant-run restaurants, fruit, cigar, and bootblack stands also were eyed suspiciously as procurement venues. 5 Between 1905 and 1909, Portland mayor Harry Lane led the city's first campaign to shut down the North End vice district. As a physician and social hygiene advocate, Lane assigned both moral and physical danger to its notorious dens of iniquity. Yet, his anti-prostitution campaign was handicapped by long-standing ties between powerful vice-related property owners, corrupt policemen, courts and city officials. Even after firing the entire vice detective squad in 1906, corruption in higher circles stymied the crusading mayor's efforts. Payoffs and favors all throughout the system gave little incentive for honesty at the patrolman's level. Lane endorsed Baldwin's new police program because she had been an ally in his battle against the city's vice interests since her work for the Travelers' Aid in 1905.6

The North End district boasted the usual features of western port cities. Merchant seamen, loggers, farm hands, and soldiers from nearby Vancouver Barracks strolled its cobbled streets in search of a "good time." Blocks of shanty "cribs" inhabited by solitary prostitutes coexisted with grand bordellos like the Paris House at North Third and 
Davis, where up to a hundred "sporting women" resided. More modest operations such as the Keystone Saloon at Fourth and Flanders had connecting doors which led upstairs to small partitioned rooms. These spaces ostensibly qualified saloons as "hotels," allowing them to circumvent sunday closing laws. Although barely large enough for a cot and a washstand, Baldwin discovered that these vestibules usually rented to prostitutes for $\$ 15$ a week. Tony Arnaud's place at Fourth and Everett featured much the same attractions. In nearby Erickson's, Fritz's, and Blazier's saloons, young women who "rustled" drinks for the management could be had for other entertainment as well. Dubious "massage parlors," ethnic restaurants, and various small businesses rounded out the North End core. 7

Because authorities believed that prostitution thrived within an international white slave network, Baldwin's work involved her in federal immigration cases. Soon after her swearing-in, Portland's police chief authorized the new policewoman to aid government officials and the federal courts in such investigations. Within her first month of duty, Baldwin helped deport a young Japanese woman who had been placed in a Portland brothel "by a Jap who had lured her from Tokio [sic]." The next year, she assisted in deportations of a young "Russian Jewess" and a Chinese girl. Both had been procured by the son of one of Portland's main crib operators for work at his Astoria "annex." The 
immigration bureau kept tabs on these "maques," or pimps, informing Baldwin in mid-1909 that it knew of at least forty such men "having headquarters in Portland." Although deportations were normally carried out through seattle, the policewoman sometimes had to transport alien girls much farther. In one instance, she accompanied two girls to New York City for processing. 8

Baldwin's encounter with one young woman provided a fitting characterization of the prostitution "system" she and Mayor Lane sought to eradicate. Acting on a tip, the woman detective made a late-night visit to "the crib at 86 North Fourth street," where an informant reported the occupant to be "less than eighteen, although she claimed to be twenty-two." As a precaution, the policewoman asked her hack driver to stand guard on the street so that prospective customers would not interrupt the interview. The girl, "Emma," appeared to be "about eighteen." Baldwin's report described her as "a young Jewess, pretty, does not look dissipated, says she does not use liquor, smokes sometimes, but is not addicted to it." The girl told the detective that she came from New York, and had only taken the crib "to fill in when other girls were absent." She acknowledged that she was employed by the same man who recruited the two Astoria prostitutes whom Baldwin had helped to deport, and that she had worked for him "in a number of Northwest cities." "Jake," her pimp, did not fear prosecution, the young woman 
declared, as he claimed that "the policemen were all his friends, and he could do as he liked."9

Collusion between vice operators, city police, and officials continually plagued Lane and Baldwin's anti-prostitution efforts. Acknowledging enforcement difficulties, city councilman George L. Baker warned Lane that prostitutes would simply scatter throughout town if the mayor closed down the North End. Taking a "regulationist" position, Baker and others who agreed with him urged that the city simply require licensing of brothels and "red light ladies" in a segregated district. In response, hundreds of small-business and middle-class Lane supporters mounted a petition drive to demonstrate their commitment to the mayor's social hygiene paradigm. Answering complaints that police procedures against prostitutes were overly harsh, petitioners asserted that any short term "evil" would be more than offset "by the gain in decency, in social cleanliness and in the purification of the atmosphere in which our families must live."10

Lane's persistence, and the public outcry, caused some prostitutes to depart the North End and led to the arrest of others. Baldwin tracked one girl from a local crib to a Salem brothel. The madam at the capital city bawdy house told the policewoman that few other Portland giris had come there, because the sheriff met the trains "and did not allow any of them to land." Back in the Rose City however, Baldwin 
discovered that prosecutions were uneven at best. Edging toward an acknowledgment of equal gender culpability, she noted in her logs that one judge performed "an injustice" in his treatment of the men and women arrested at the cadillac rooming house. The males were fined $\$ 25$ and released, Baldwin reported, but the females were assessed $\$ 50$ and put in jail. The policewoman begged another bench official to take her solicitation arrests more seriously. "It is useless for us to work," she remonstrated, "unless we can obtain convictions." One long-tenured circuit Court judge flatly told Baldwin that he "would never send a man to the penitentiary for a carnal crime, especially if it be his first offense."11

Discouraged and fatigued by his failures, Harry Lane lost his re-election bid in the April 1909 primary. During the mayor's lame-duck months, Baldwin discovered the truth of previous warnings that prostitution would spread to other areas of the city. She had not anticipated, however, that the sex trade would reappear under new guises. "The massage parlors, and the places of fortune telling and palmistry, and others of like cult," the superintendent's logs reported, "are simply blinds for assignation houses." Shooting galleries, and other predominantly male-attended amusements which employed young girls, also came under scrutiny. Lane directed the policewoman to make a comprehensive inquiry into the matter. Since Baldwin had 
prosecuted massage parlors through her work at Travelers' Aid, this was not new territory. At the mayor's request, the policewoman set about "endeavoring to get proof against them." 12

Baldwin began with a systematic investigation of the thirty-plus massage businesses duly licensed by the city. She applied two investigative methods in the survey. During daylight hours, the superintendent personally visited parlors and demanded to inspect their records, licenses, and equipment. If she suspected something immoral, she sent a male investigator back for an evening visit. On one typical nocturnal mission, her informant reported that he was greeted by a young woman in a silk kimono. As he awaited his turn "for a massage," he could hear male voices beyond the wall. When the investigator asked the hostess if men could stay all night, she replied affirmatively and said "it would not be over five dollars" to do so. The place in question had been closed by the mayor on Baldwin's advice the previous year, but had been allowed to reopen by the city license committee. The policewoman again brought suit but was rebuffed when the presiding judge found insufficient other complaints against the establishment to close it. Baldwin thus realized that massage parlors could avoid "common fame" charges if they relocated before enough remonstrances accumulated against them. 13 
of the thirty-two licensed massage parlors operating in Portland in the spring of 1909, Baldwin obtained evidence that thirty "were either houses of assignation, or places of very shady repute." Such a proportion convinced the policewoman that current licensing regulations abetted the perpetuation of disreputable businesses. Declaring "war on the whole proposition," she rewrote the ordinance governing massage parlors and submitted it to the mayor and council. To protect legitimate practitioners and guard against immorality, the revision proposed that women could not give massages to men unless a male attendant were present, and visa-versa. Baldwin's testimony before the city council won approval of the revised ordinance, and Mayor Lane signed it into law in the last week of his tenure. Under its

provisions the thirty offending parlors were shut down. When the new city administration took office the next week, the incoming chief of police offered Baldwin his "hearty approval" and instructed her to proceed with her vice monitoring. 14

The new chief's endorsement was significant because the fate of the women's police had become a political football in the 1909 mayoralty race. In January, candidate Allan G. Rushlight, chair of the city council ways and means committee, had sought to eliminate Baldwin's department by cutting off its funding. The policewoman complained that Rushlight represented "saloon interests" who were opposed to 
her dogged anti-vice work and wanted to tag her as "a Lane appointee." Support from the mayor, police chief, the Evening Telegram, the oregon Journal, and women's groups saved the program and in Baldwin's words "amicably resolved" her budget problems. Nevertheless, the Rushlight incident sensitized supporters of the women's protective auxiliary to the agency's vulnerability. Baldwin and her purity allies decided to avert potential political reprisals by seeking to establish the women's division as a permanent part of city police protection. To do so, the social hygiene coalition placed a city charter amendment before voters in the June election. On the day that Portlanders tapped former United States senator Joseph Simon as their new mayor, they ratified the women's police amendment by nearly a thousand votes. 15

Bolstered by her victory, Baldwin tested Simon's anti-vice mettle. In August 1909, the Evening Telegram suggested that the policewoman look into the activities of several "introducing and matrimonial bureaus" appearing across the city. Suspecting something along the lines of the massage parlor scam, she personally visited the places in question. On September 4, Baldwin reported her findings to the mayor. She discovered that a matrimonial agency in the Alisky Building was run by a well-known abortionist. At a business on First street, the policewoman found private rooms where male and female clients met "promiscuously for 
evening basket suppers, etc." The last introduction service she investigated was owned by a woman who had been driven out of seattle "for conducting an immoral business." Simon immediately sent the report to the health and police committee of the city council. The panel recommended passage of a prohibiting ordinance and the full council adopted the measure on september 22. Simon's rapid response made it clear to the head policewoman that he would support her ful1y. 16

Although simon had gained a political reputation in the Senate as "a master of compromise," he presented a rigid position on the social evil. Warnings about prostitution and venereal disease from social hygienists clearly affected the mayor's policy. Having no part of the regulationist argument, simon set out to abolish the locally-recognized "restricted district" north of Burnside Street that Harry Lane had been unable to close. Baldwin supported the mayor's abolitionist position. Yet, both simon and the women's police superintendent appeared to be challenged when charles Crittenton, founder of the Florence crittenton chain of rescue homes for prostitutes, spoke at a Portland church in the fall of 1909.17

Newspaper reports of crittenton's talk seemed to suggest that the aging reformer favored segregated vice. The next day, simon invited crittenton to city hall to debate the issue. Meanwhile, Baldwin sent a letter of support to 
the mayor. As a past board member of several crittenton homes, the superintendent declared, she could not believe that the founder would advocate restricted vice. The prevalent opinion among social workers, she sniffed, was that "segregation [was] simply incubation."18

At the mayor's office meeting, crittenton denied that he had advocated retention of Portland's vice district. What he had intended, the reformer suggested, was a "go slow" warning. If sympathetic efforts were not made to rehabilitate former brothel inmates, argued crittenton, they would eventually resume their old lives here or elsewhere. Regretting the misunderstanding that he had wanted to interfere with city policy, Crittenton insisted that he had simply voiced a concern over the harsh police treatment of North End women. Simon assured the reformer that "only humane methods" would be used against prostitutes. Accepting the mayor's response, the frail Crittenton left Portland. Barely two weeks later, he died while lecturing in San Francisco. 19

Once Crittenton had clarified his position, Baldwin retracted her public criticism, but reiterated her support of the mayor's actions. "If the underworld cannot have a wide open town," she wrote, "their next choice is a restricted district, and we have made a splendid start toward defeating their end thus far." The policewoman told the mayor that crittenton seemed out of touch with recent 
changes in his own organization. She had visited many of the Crittenton homes across the country, Baldwin informed simon, and had met with Dr. Kate Waller Barrett, the chain's

national manager. As was true in Portland, she observed, the homes no longer dealt with prostitutes as a class, but with unwed mothers. Rather than attempt to rehabilitate hardened cases, Baldwin believed it more fruitful to prevent such girls from becoming prostitutes. For confirmed brothel inhabitants, Baldwin advocated special segregative facilities. 20

Baldwin's own observations of Portland vice conditions appeared to be borne out by a six-month inquiry conducted by a New York county grand jury in 1910. Investigators could find no evidence of the much-touted international market in women. Yet, foreman John D. Rockefeller, Jr. reported that a practice of sorts was carried out by persons "acting for their own individual benefit." Although the Rockefeller report seemed to puncture the great "foreign conspiracy" theory, it left enough of it intact to legitimize local abatement programs. It also spurred the federal Mann Act of 1910, which forbade the inter-state transport of women for immoral purposes. A contemporary report by Chicago's Law and order League strongly reiterated the sentiments against commercialized sex and reaffirmed the threat of venereal disease. As Baldwin forwarded her copies of both the New York and Chicago summaries to Simon, she noted that her 
department was "much pleased" with his continued vigilance over the social evil.21

The Mann Act proved a valuable tool for Portland's head protective worker. Many of Baldwin's prosecutions involved soldiers from Vancouver Barracks, a brief ferry ride across the Columbia River in Washington. Rail passage between Portland and Seattle, Spokane, and other Evergreen State cities also figured in several of her cases. The federal law allowed the policewoman to bypass local judges who had been less than cooperative. Her success rate was enhanced again in 1911, when Oregon's legislature passed a "little Mann Act" which applied the federal criteria to intra-state transportation cases. The state law enabled Baldwin to get control of the roadhouse "joyriding" problem that persisted outside city limits. Between 1910 and 1912 , her log reported eighteen cases involving the federal and state anti-trafficking laws. The strangest of these prosecutions involved a "man" arrested for bringing a woman to Portland from Spokane. "He" turned out to be a female with "an almost insane mania for making love to girls while dressed in men's clothing." 22

When a grand jury accused Joseph Simon's hand-picked police chief of "malfeasance in office" in 1911, the Portland Municipal Association joined other civic groups in charging that the mayor had been ineffective in closing down the vice district. His fellow Republicans then refused 
to support him, and he lost his re-election bid. Past experience with mayor-elect Allan Rushlight gave Baldwin suspicions of his commitment to vice reform. In the interim between Rushlight's election and inauguration, the policewoman joined in a growing movement to explore the possibility of forming a vice commission in the Rose city. Following New York's lead, a number of Progressive era municipalities had appointed such bodies to make systematic statistical surveys of prostitution and venereal disease and to provide city officials with recommendations. In concert with a group of physicians, churchmen, juvenile court and social welfare workers, Baldwin hoped to influence the incoming mayor to take such a step. 23

In one of his first official communications on the subject, Rushlight made a somewhat-vague address about opposing a "wide open" town and seemed amenable to the idea of letting someone else formulate the city's vice policy. Local commission boosters seized this opening and began a serious research and lobbying campaign. Baldwin had her assistant take library notes on the recent voluminous report of the Chicago Vice Commission. The superintendent herself corresponded with Arthur B. Farwell, president of the Chicago Law and order League, whose group had spawned that city's vice query. Farwell sent Baldwin his encouragement and a large packet of news clippings about the vice commission's formation and plan of action. The policewoman 
passed this information on to Portland's citizen anti-vice committee. 24

Rose City vice commission activists decided to base their efforts on the Chicago model. Accordingly, they drafted an enabling ordinance and introduced it to the city council in August 1911. Episcopal clergyman Henry Talbot, the group's leader, urged local ministers to put pressure on the ways and means committee to appropriate the $\$ 3,000$ needed to fund the commission. The amount was a bargain, contended Talbot, since the same work had cost $\$ 5,000$ in Chicago, and $\$ 10,000$ in New York. Meanwhile, a suspiciously hesitant Rushlight refused to name members to the proposed board until it had the assured funding. At about the same time, however, Oregon reform governor Oswald West expressed displeasure with Portland for non-compliance with his statewide anti-vice agenda. Since Rushlight had told West he was waiting for a vice commission review, the mayor was backed into a corner. On September 24, Rushlight bowed to the pressure. The ways and means committee suddenly "found" the money, and the mayor named fifteen commissioners. His list included most of the original activists who supported the idea, Baldwin among them. 25

The Portland Vice Commission began its activities in late 1911 by mounting a comprehensive local survey of the venereal disease problem. With a third of the city's physicians responding, the commission estimated that 
venereal cases represented "almost a quarter of the disease" seen by doctors. In January 1912, the panel recommended that infected persons be reported to health officials and legally subjected to treatment. The vice commission report included special praise for the venereal disease education efforts of the local Social Hygiene Society. It called for the creation of free dispensaries and clinics to be run by the Board of Health. The commission further proposed that the city should pay the cost of venereal isolation wards in existing hospitals until it could build a specialized, separate "medical detention" facility. Such official conclusions reiterated member Baldwin's musings of three years earlier that "some means ought to be devised" whereby diseased girls could be committed to curative institutions "for the good of the community." 26

As its next objective, the vice commission began a rigorous investigation of commercialized prostitution. But in July 1912, it became bogged down in the old argument of whether abatement or a restricted district was the preferred solution. Although work pressures had forced Baldwin to resign from the vice board, she made the time to voice her opinion at a special hearing on the matter. In a move that bristled city hall, an impatient Governor West had recently threatened that he would give the head policewoman "a free hand" through special state enforcement powers if portland did not hasten its vice-remedial actions. The current 
discussion seemed deliberately calculated to slow the work of the appointed investigative body. Indeed, sources close to Mayor Rushlight made it known that they felt the commission had no real authority to institute changes, but only to "make reports and recommendations." 27

At the city hall meeting, Rushlight opined that a controlled district "would be better than present conditions." Surprisingly, a juvenile court judge who also served on the vice commission agreed with the mayor. However, the judge cautioned, such an area should be "stringently regulated, with no liquor, or chance for men to live off the earnings of women." Baldwin argued against them both, vehemently stating that she was "unilaterally opposed to any kind of a restricted district." While current conditions were not perfect, she conceded, they were "far better than they ever were." Recent vice raids which the mayor dismissed as useless, she countered, were in fact having a deleterious effect in the North End. Prostitutes had admitted to Baldwin that they could no longer carry on their trade "for fear of molestation" and procurers could not "get any new recruits." Hinting at the specter of Governor West, the policewoman further reminded listeners that, "by state law," brothels could not be "recognized or condoned." By the end of the session, the befuddled mayor admitted frankly that he did "not really know how the problem should be handled" and deferred to the vice commission. 28 
On August 23, the commission's findings made headiines. of 547 suspected prostitution venues, 431 were confirmed to be "immoral." of greater significance, perhaps, was the report's public disclosure that many vice-infested buildings were owned by prominent men. With heavy profits from their investments, few seemed to care how the properties were used. Aghast at this "absence of a keen sense of personal responsibility" among the wealthier class, the vice panel made two earnest recommendations. First, not unlike Baldwin's usual practice of publishing the names of lodging houses which harbored prostitutes, it asked for a first-in-the-nation "tin plate" ordinance. Such a measure would require the owners of saloon buildings, hotels, boarding, and lodging houses to post their names on their holdings. Second, the commission asked that all lodging facilities be inspected and 1 icensed. Under continued commission pressure and the vigilant eye of the state executive, the city complied with both requests. Within months, despite its reluctance to do so, Portland found itself the source of a model action that soon would be copied and praised by other municipalities. 29

The third part of the vice report, issued in December 1912, considered the "legal and police aspects of the social evil." In one of many complaints about prostitution conviction rates, Baldwin had confided to a Portland judge that she and her assistants "might as well be seat warmers 
and clock watchers," for all the support they got in the courts. The commission's report confirmed these frustrations. Less than 50 percent of almost 1900 prostitution arrestees were convicted in the previous eighteen months. Of 216 establishments raided in the same time period, the report continued, not one had been put out of business. In an attempt to overcome the local "failure to get results," the vice panel turned to state-inspired remedies. Because there were duplications and discrepancies of jurisdiction and law among Oregon's towns and cities, it proposed an "end run" solution by requesting a uniform state abatement law. The commission also asked for a statute mandating a separate, state-level "morals court" in counties (Portland's Multnomah) of over one hundred thousand population. Such measures were necessary, the report suggested, "to afford the decent element some relief from present conditions in an orderly and lawful manner." When the next legislature enacted both codes, the city's segregated vice district was all but history. 30

The Portland Vice Commission uncovered "118 instances" of police graft or similar irregularities. Accordingly, it asked that the city review its civil service requirements for law enforcement officers. The panel strongly suggested that more emphasis be placed on "moral qualifications" for duty. In addition, it recommended that all police personnel be instructed in the "laws of evidence" so that cases would 
no longer be lost in the courts because of unprofessional methods. Furthermore, the department was advised to keep more comprehensive records and statistics, such as Baldwin's section had provided since its inception. The commission also found weaknesses in the division of authority and the governing structure of the police department. Many of these structural problems were addressed in 1913, when municipal voters approved a change to the "Galveston Plan" commission form of government. 31

The creation of the Portland Vice Commission was the turning point in the city government's official attitude toward sexual vice. This change may be directly attributed to the pressure of a strengthening local social hygiene movement, backing by a similar-minded state legislature, and the guidance of reform-minded Governor oswald West. Indeed, the Rose City's next mayor, former state senator H. Russell Albee, a long-time ally of Baldwin's, had been a significant force in Oregon's passage of progressive anti-vice laws. Despite these influences, Lola Baldwin's presence in the women's police division had a major impact on law enforcement approaches to prostitution and other social crime. Significantly, the vice commission's third report showed unequivocally that Baldwin had instituted "professional" standards fully five years before the vice survey mandated such reform in the city's male police ranks. Through persistence and the judicious use of state and 
federal codes, Portland's head policewoman made remarkable progress in overcoming the corruption and lax methods of the local bureaucracies and courts. 32

Spawned by nationwide vice commissions, city and state abatement laws inaugurated "the passing of the red light district." The process was completed by federal sponsorship of the "American Plan" of sexual hygiene for World War I military personnel. By wartime, the social hygiene movement had become so influential that "abstinence" became the official watchword for soldiers and sailors traditionally among the brothel's best customers. In 1917, leaders of the American Social Hygiene Association and its affiliates put together a plan of action under the direction of secretary of War Newton D. Baker. The program provided mass sex education and venereal disease warnings for recruits, closed the remaining red light districts, and mandated nationwide "moral martial law" in or near military facilities. One segment of the effort, organized by Raymond B. Fosdick, head of the War Department Commission on Training Camp Activities, called for protective policing of girls and women who lived or worked close to such installations. 33 Katherine Bement Davis, the first director of the federal female protective section, initially had assumed that the agency would be preventing the sexual ruin of innocent girls by libidinous recruits. Within six months, however, experience showed the opposite as a new class of 
delinquents surfaced. Apparently smitten by what one reformer called "uniformitis," young "charity girls" or "patriotic prostitutes" sought to help the war effort by dispensing free sexual favors to servicemen. Social hygienists found that such delinquents often outnumbered "good" girls in training camp areas. The problem required the federal women's protective service to reorganize. In early 1918, the agency added a law enforcement component to deal solely with the legal restraint of delinquent girls from "almost unchecked access to the enlisted men." Training Camp Commission chairman Fosdick put out a call for persons experienced in the field of women's vice policing. One of his advisors, Maude E. Miner of New York, recommended Portland policewoman Lola Baldwin. 34

Fosdick asked Baldwin to be his northwest field secretary in February 1918, and the Rose City granted her a "wartime service" leave. In her new capacity, the policewoman began to prepare Portland and other northwest cities for "war emergency" morals restrictions. Portland had already strengthened its lodging house codes, and finally appropriated money for the women's venereal detention facility mandated five years earlier by the vice commission. Baldwin's new federal mantle gave her power to ask for whatever local cooperation she deemed necessary. In late February, she requested and received an amendment to the solicitation ordinance making it "unlawful to bring together 
people for immoral purposes" via public transport, private automobile, telegraph, or telephone. A month later, Baldwin obtained a long-demanded increase in the number of policewomen when her Women's Protective Division was directed to hire six new female officers "subject to general police duty." Ironically, the enabling ordinance justified the expansion as necessary "so that better protection be afforded the boys serving their country."35

To facilitate the work of the Commission on Training Camp Activities, the federal government divided the country into nine geographical districts. By the summer of 1918 , Baldwin had been promoted to supervisor of the law enforcement division of the Seventh District, which covered the entire Pacific coast. The position required her removal to San Francisco, where she set up an office in the Flood Building on Market Street. The reorganization of the women's section completely relegated protective and recreational work with non-delinquent girls to local YWCAs, Girls Clubs, and other voluntary groups. Officials like Baldwin dealt exclusively with sexually delinquent girls and women. Within a five-mile radius of any military facility on the west Coast, she and her "fixed post representatives" maintained the authority to arrest any female even suspected of sexual immorality. 36

Although some of the girls handled by wartime morals agents had arrest records for prostitution, others were 
detained for "loitering around parks, beaches, or the vicinity of training camps, or because they were thought to be diseased, runaways, or incorrigibles." Nationwide, almost 16,000 girls, "average age twenty," were remanded to jails, detention facilities, venereal hospitals, or "farm colonies." Many were held under indeterminate sentences. Through the study of their case records, these young women became the unwitting subjects of the first comprehensive national survey of female delinquency. Two of the detention places for Portland-area girls were midwived by Lola Baldwin. In 1913, she had convinced the legislature to build Oregon's Hillcrest female detention home in a rural area near Salem. The Portland women's police superintendent later helped formulate plans for "The Cedars," the venereal and sexual delinquency facility erected in the Rose City in 1918 as a "wartime emergency" measure. During the war, a total of seventeen such places were constructed under the direction of the federal morals program. In the west's seventh District, Lola Baldwin put her personal stamp on those in Portland, Tacoma, San Diego, and Los Angeles. 37

When hostilities ceased in November 1918 , the government opted to continue its "moral martial law" until demobilization was complete. Jane Deeter Rippin, then national director of the women's section of the Commission on Training Camp Activities, begged Baldwin to stay on until the War Department no longer needed her. Consequently, 
the women's protective worker extended her leave and remained in San Francisco until the end of 1920. Often called to Washington D.C. to advise superiors, Baldwin received praise from officials such as Raymond Fosdick, and from the military medical officers she worked with on a daily basis. Substantially through the wartime efforts of the women of the Law Enforcement Division, Fosdick wrote, "the red light district practically ceased to be a feature of American city life." 38

By employing coercive state practices to combat prostitution, the federal women's enforcement bureau helped enable social hygienists to claim that the commercialized vice district had been eliminated. Their concerted anti-venereal disease campaign in both civilian and military arenas also frightened or coerced many males into practicing a single standard of sexual behavior. Through federally-sanctioned wartime tactics, women's protective workers helped foster a marked change in law enforcement attitudes toward the prostitute on the local and national level. Under martial law regulations, Baldwin and others had arrested 35,000 women and girls merely on suspicion of immorality and held them without due process for extensive periods. No men, however, were prosecuted for patronizing prostitutes. Because the government continued its morals policing well beyond the war's end, the stereotype of the "criminalized" prostitute became ingrained in the minds of 
enforcement agents and the public. Such imagery upset lingering depictions, prevalent in the prewar years, of prostitutes as unwilling "white slaves" or victims of male lust. Postwar characterizations now tagged such women as sexually deviant and diseased criminals who brazenly victimized men and their innocent families and deserved incarceration. 39

Baldwin's career traced the national change in attitudes about the prostitute. In the late nineteenth century, the volunteer protective worker shared Charles Crittenton's "Social Gospel" moral doctrine that prostitutes were victims who could be morally rescued and occupationally rehabilitated. Her work with the YWCA-supported Travelers' Aid continued to reflect this belief in the possibility of rescue. As a professional policewoman, however, Baldwin's daily experience and "scientific" evidence on female delinquency caused her to doubt that certain girls could be helped. By 1908, the women's auxiliary superintendent had clearly discarded Crittenton's "moral" approach for a more "professional" analysis which couched prostitution as a medical problem. Acknowledging the rising popularity of the social hygiene movement's anti-disease orientation to vice control, Baldwin used it to get results in her police work. When its momentum spawned the Portland Vice Commission, the policewoman's faith in the social hygiene agenda multiplied. During the 
war, moreover, Baldwin's federal police powers enabled her to secure additional vice legislation and spur the creation of local and western-regional detention facilities. 40

The social hygiene movement empowered Baldwin's new profession and person in a manner she probably could not have engineered on her own. Yet, the relationship was necessarily symbiotic. The social hygiene agenda was fulfilled only through increasing degrees of state control. Although reformers like Baldwin and Harry Lane quickly embraced the medical model of vice control, it took years for the enforcement apparatus to catch up. While mayors Lane and Joseph Simon sought abolition, remnants of regulationism and simple old-fashioned graft prevented its implementation. Eventually, the social hygiene element assumed its own police power through the vice commission, which allowed it to neutralize Mayor Allan Rushlight's ambiguity on the issue and to mold the courts and male police force to its purposes. The federal government, however, provided social hygienists like Baldwin with the ultimate control mechanism by suspending habeas corpus for suspected prostitutes during wartime. 41 


\section{CHAPTER V}

CONCLUSION: THE LEGACY OF THE POLICEWOMAN

Baldwin returned from her government hiatus to resume her Portland position in late 1920 . The reinstated superintendent immediately detected rancor between her old department and its city hall superiors. Back under the authority of the mayor and city police chief, she found herself curtly ordered to eliminate the six extra policewomen hired as a wartime measure. Part of the problem stemmed from her temporary replacement in the women's protective division, Mrs. E. J. Frankel. Frankel had raised the ire of Judge George Tazewell of the Juvenile Court by repeatedly remanding underage girls to the city venereal facility without court permission. Tazewell strongly opposed harsh federal wartime morals guidelines which allowed detention of sexually delinquent girls without due process. objecting most strenuously to forced contact between under-age delinquents and hardened adult offenders, the judge complained to city officials that it did not "improve the morals or the future of any girl to be kept with such women." The matter embroiled Mayor George L. Baker, Chief Nelson Johnson, Tazewell, and Frankel in a lengthy and divisive debate. Baldwin's higher-ups now told her that she 
would "be held fully responsible for results in the women's division" once she reduced it to prewar numbers. 1

Having worked for two years with scores of like-minded reformers in the War Department's morals squad, Baldwin was surprised by Tazewell's attitude. After visiting venereal institutions in other cities, the policewoman later wrote, she found The Cedars to be one of the best conducted and most efficient of its kind. "Though most of the girls are detained against their will," the women's division head confessed, "no girls have ever complained to us of either treatment or care." other problems became apparent to Baldwin as well. The removal of wartime restrictions bared a Portland with drastically changed social and cultural mores. In late 1921, for example, the policewoman publicly decried a new custom of dance hall weddings and openly criticized Judge W. N. Gatens of the Circuit Court for conducting such ceremonies. Gatens rebuffed her objections, and protested that he "believed such marriages were proper," insinuating that Baldwin was out of touch with modern mores. 2

Driven to explain the reasons for the moral relaxation around her, Baldwin bared her soul to city authorities in a letter of early February 1922. She was "forced to admit" that moral conditions had worsened "since the War." Although partly blaming a reaction to the lifting of wartime restraints like those she had put in place in her federal capacity, Baldwin cited other reasons as well. She 
complained that high wartime wages "did not benefit the home 1ife, nor make for thrift and industry as might have been expected." To her dismay, a nation on the threshold of the "Roaring Twenties" had eschewed thrift for consumption. Baldwin particularly disparaged the young "flapper," whose short skirts, bobbed hair, rouge, and lipstick, made a "poor substitute for the modest beautiful young American girl of yesterday." The couture of the prewar "bad" girl now hung in practically every young woman's closet. Youth delinquency was on the rise, and "liquor, automobiles, and dancing" appeared in most cases. For this, she primarily blamed "the results of too much freedom and a general lowering of standards in the American home." Until conditions in the home improved, she warned, social agencies and policewomen would "be unable to cope with the situation." 3

Appalled that the demeanor her generation associated with the prostitute had become the norm, Baldwin lashed out at the example set by the "new woman." The most insidious behavior effected by postwar female culture was cigarette smoking. "This habit," the superintendent remonstrated, "which once would have ostracized any woman and classified her with the underworld, is now in common use among women and girls who would have us believe they are decent." The formerly male-only addiction had "reached our schools, colleges, and social functions" and was even "practiced by 
some professional women." Baldwin claimed to have caught girls as young as six trying to smoke, "as they had observed their elders doing." Somewhat at a loss, the policewoman appeared to confuse a "sadly declining" state of postwar morality with an attempt to define a modern set of mores. Disillusioned, perhaps, by the pyrrhic results of her coercive social hygiene program, the superintendent elected to retire a few weeks after sending her letter to the mayor, police chief, and local newspapers. 4

Baldwin handed her responsibilities over to Martha Randa11, a Portland policewoman since 1913. Still concerned with delinquency problems, the now-retired superintendent traveled frequently to other cities to lecture on preventive work and encourage the formation of women's divisions. The former policewoman also served as the western representative on the board of the National Committee on Prisons and Prison Labor. During the 1920s, this board formulated occupational training programs for women's penal institutions which were reminiscent of Baldwin's pre-industrial regimen for the inmates of Oregon's Hillcrest reformatory. Besides these activities, in ensuing decades the retired vice officer kept a finger on the pulse of the Women's Protective Division, and wrote numerous newspaper letters and opinion pieces on women's policing issues. The nation's first municipal policewoman continued to be a conscience for traditional morals until her death in Portland in 1957 at the age of ninety-seven. 5 
Sociologists Robert Liebman and Michael Polen have described police "professionalization" as the end result of "shifts in responsibility" for law enforcement or crime prevention. Over time, they have argued, the burden of policing transferred from part-time volunteers or vigilantes to full-time private or state-paid agents. In light of Liebman and Polen's thesis, Baldwin can be seen as the principal "transition figure" of the American policewomen's movement. She began as a volunteer investigative worker for late nineteenth-century homes for prostitutes, unwed mothers, and wayward girls. Later, Baldwin translated her experience into paid preventive and investigative work for the Travelers' Aid. When she convinced Portland to hire her as the nation's first policewoman, Baldwin turned female vice-prevention into a public necessity. 6

Don s. Kirschner portrayed the Baldwin type of Progressive era professional as one trying to escape the "do-gooder" image. Although Travelers' Aid paid Baldwin to coordinate its activities, it relied mainly on "society matron" volunteers seen by many as moralistic "busybodies." In contrast, Kirschner has argued, professionals were respected for being "not only well-intentioned, but...clear-minded, practical, detached, scientific, and generally right." At a certain point in what Kirschner describes as the "drift toward professionalism," Baldwin began to apprehend "a sense of special identity" in her 
activities. By developing standards and procedures such as a cross-referenced case data system, periodic statistical reports, "preventive" policing, and an "after care" parole program, she exuded what Kirschner has portrayed as "both the image and the reality of professionalism." The language of Baldwin's 1907 report to the city indicated that she distinctively perceived herself as a "policewoman" of three-years standing. The superintendent demonstrated this again in 1913 when she overruled an outside consultant who arbitrarily tried to place her agency under the Municipal court. 7

Middle-class interest in preserving traditional female purity played a central role in the emergence of the women's police. As David J. Pivar and others have documented, many Americans feared the perceived changes in moral values which accompanied urbanization. For some, the source of anxiety lay in corrupting effects of industrialization like "democratized" amusements. Others decried the moral decadence of the "new" immigrants, a perception enhanced by the specter of an Anglo-Saxon race decimated by venereal disease and "inferior" bloodlines. Many middle-class concerns focused squarely on the "girl problem." For that reason, Baldwin mentors like Portland mayors Harry Lane, Joseph Simon and $H$. Russell Albee and Oregon governors George Chamberlain and Oswald West believed that female influence was essential to government. Women were seen as 
crucial partners in a "parental" state that would assure the reiteration of traditional morality standards through government interdiction. When a combination of social and moral problems mushroomed into local and national crisis, taxpayers became willing to pay for women's vice policing. 8

The Progressive era presented a classic "window of opportunity" for Baldwin's energies. During this period of extensive reform and restructuring in American 1 ife, traditionally-empowered men became more receptive to the idea of women as legitimate agents of the state. Liebman and Polen have suggested that desire for political power partly motivated those who sought control over policing. Through her authorship of legal codes regulating the lives of young females, Baldwin assumed elements of such power. In some cases, she drafted legislation five years before Oregon women gained suffrage in 1912. Shortly before the state's women participated in their first election the following year, Baldwin's staff spent several days facilitating voter registration. The political authority sought by these women was simply a modicum of control over their own lives and status. Once they gained the vote, Portland's women championed those officials who helped their special causes. In 1ate 1914, for example, Mayor Albee barely survived a recall attempt. In a post-election letter to Baldwin, he claimed that much of the credit for the positive outcome was 
"due to the women of Portland, who supported this administration well." 9

Although her occupational raison d'etre presumed an inherent female "difference," Baldwin fiercely defended her own and her subordinates' professional equality. She firmly believed in "equal pay for equal work." Although rated as a detective, the policewoman began duty in 1908 at a captain's salary, a point of some contention. Noting, four years later, that an assistant had not received the third-year pay increase given male officers, Baldwin pushed the issue with the city. "If a woman performs her duty as an officer as faithfully as a man," she wrote to the chairman of the ways and means committee, "she should be entitled to the same kind of remuneration." The superintendent also complained that her stenographer, "a widow with a child to support," was receiving less salary than her status as a civil service employee dictated. This discrepancy, too, was rectified. Baldwin fought for pay equity right up to her retirement in 1922. One of her last official communications to the mayor and chief of police begged that her policewomen finally be allowed overtime pay. 10

Because Progressive era thought decreed that females were "naturaliy" suited to positions which oversaw the welfare of other women or children, Baldwin gained a legitimate niche as a policewoman. Her 1905 appointment as a juvenile court probation officer was another case in point. 
Officially, Baldwin always was careful to maintain the appearance of a certain dependence on "male wisdom." In her later years, she told an interviewer that she earned the respect of her masculine cohorts "primarily by being a woman doing woman's work, not a woman encroaching on male territory." The superintendent sometimes reiterated the point when it distinctly served her department's advantage. In 1912, for instance, when the police bureau threatened to withdraw a male officer who had been helping Baldwin with an above-average caseload, the overworked policewoman begged her chief to reconsider. "While I believe there are some things women can do better than men in this work," she pleaded, "there are other things which demand the attention of a man." 11

Progressive era female reformers such as Baldwin were required to perform a delicate balancing act between customary male and female roles. As she gained a foothold in a public sphere traditionally dominated by men, the policewoman was especially vulnerable to the particular tensions and ambiguities of the post-Victorian age. On the one hand, Baldwin based her police work on the idea that females were somehow different and in need of state protection. At the same time, she championed equal suffrage as a way for women to determine their own legal destiny. She apparently reconciled many of the gender prejudices of the times via her professional status. Baldwin treated her work 
place as a refuge which existed outside traditional sex classification. Within the structure of her profession, the superintendent was free to demand the same deference, salary, equipment, and office accomodations as her male cohorts. In the same way, her official role, and its presumed expertise, gave the policewoman entry to the city and state political and legislative process years before the advent of oregon women's suffrage. 12

Portland's Baldwin should be recognized as the founder of the policewoman's movement in the United States. Nevertheless, even recent police histories have awarded that role to social worker Alice Stebbins Wells, who began a similar career in Los Angeles in mid-1910. Such factual error can be traced to a 1925 study of the women's police movement by Wells protege Chloe Owings. Even a cursory examination of Baldwin's ample records and logs disproves the notion that the founder of the Los Angeles women's police was the nation's pioneer in the field. 13

Baldwin recognized her work as a distinctly new women's profession, and sought to spread the word to other cities. She noted that by mid-1913, eighteen American cities had hired policewomen. Most of the early women's divisions could directly trace their roots to the personal encouragement of the Portland superintendent. When her schedule permitted, she lectured in cities which contemplated using women police. If she were unable to visit, Baldwin freely sent on 
her organizational plans, program outlines, and "success" statistics. In 1909, Boston asked the policewoman to send a complete exhibit detailing her work for its future-looking "Boston-1915" Exposition. From 1908 to 1909 alone, officials in Washington state's Seattle, Tacoma, Spokane, Bellingham, and Yakima, California's Sacramento, Oakland, and San Francisco, and Richmond, Virginia either began such programs or inquired about them. Baldwin's idea became international in 1911, when she was invited to speak in Vancouver, British Columbia. The Canadian city was so impressed that it sent two female police candidates to Portland for training. Under the aegis of the National Conference of Charities and Corrections, Baldwin helped form the first national organization of women police, which elected her its president in 1912.14

Baldwin's career embodied many of the paradoxes of the Progressive era. An examination of her role in creating a new field for women and in demanding equal treatment from her male counterparts suggests a feminist model of development. Yet, such classification is fraught with problems. Although Baldwin opened up police work to some middle-class women, she closed doors for many more in the working class. The policewoman's Victorian moral judgementalism and "protective" social control, for example, eliminated the access of young women to a large variety of urban amusement jobs because of potential ties to the vice 
trade. Baldwin also distanced herself from many social feminists by refusing to endorse an absolutist position on the liquor question. Rather than put her energies into the eradication of the saloon, the police superintendent preferred to concentrate on banning women from the dreaded establishments. In sum, her obsession with sexual propriety blurred ideological lines, as further exemplified by her championing of sex and venereal disease education in a period which continued to exhibit a lingering reticence to discuss such matters. 15

Peggy Pascoe's study of the evolution of female moral authority in the West has advanced helpful tools for evaluating the paradoxes which Baldwin's career embodied. Pascoe has outlined three complex cultural changes which paved the way to modernism in the early twentieth century. First, a transformation of the victorian gender system induced a shift from the idolization of the female to an acknowledgment of her passion. Second, a decline in the cultural authority of protestant evangelicalism in a period of growing secular consumerism made pious women appear to be examples of "self-denial, repression, or religious fanaticism," instead of role models. Third, the rise of a new "cultural relativism" challenged Victorian racial theories by suggesting that no culture was more valuable or moral than another. Since these notions continued to coexist with their opposites, the Progressive era remained trapped by major anomalies 16 
In Pascoe's paradigm, the nineteenth century assigned moral authority to the pious woman. This notion carried forward to the twentieth century and persisted in protestant evangelical efforts like the YWCA. When Baldwin's work was sponsored by that organization, she was obliged to mirror its moral perception of prostitutes as victims. But when the protective worker accepted municipal (secular) funding, she felt free to make individual case judgements based on "scientific" evidence or personal experience. The policewoman could act on both the "white slave myth" and the idea of female sexual culpability at the same time. This acceptance of opposites probably made it easier for Baldwin to embrace the wartime characterization of prostitutes as criminal victimizers. 17

Imprisoned by rigid Victorianism, Baldwin failed to comprehend the evolving mores of urban industrialism. The policewoman could only perceive casual dating and mixed-sex amusements, for example, through the lens of chaperoned courtship. It seemed far beyond her understanding that giris could "have fun" and yet remain "good." Notions of racial hierarchy forced her to disparage the "negro" music and dances which the working and middle classes embraced for rejuvenation in leisure hours. As greater numbers of citizens accepted the presence of the democratized nightlife, the head morals officer persistently equated the amusement culture with vice. She could not apprehend that a 
new urban cultural consensus was demolishing the pedestal, destroying class barriers, and repudiating Anglo-Saxon moral hegemony. 18

Baldwin's militance was her greatest strength and, paradoxically, her greatest weakness. As Robert H. Wiebe has argued, Progressive era social control professionals often were deluded into believing that everyone shared their goals. This assumption, Wiebe has asserted, led them "to trample sensibilities without regard for the resentment that was accumulating about them." Baldwin's authoritarian use of police power embodied the coercive elements of the expertise so honored by progressive reformers. The apex of the police superintendent's power and influence occurred during World War I, when she had absolute discretion over the Iives of thousands of young women. She appeared most comfortable functioning within a military hierarchy under conditions of national emergency. Once cut off from martial law powers, Baldwin experienced a pessimism and despair shared by many traditionalists in the postwar era. 19

Portland's Lola Baldwin engendered the policewoman's movement at a time when the nation was undergoing convulsive changes. A "new" urban society of mixed-class, mixed-sex individuals was in the midst of forming and defining a popular culture to meet its needs. Opposed were various middle-class reformers of both genders bent on curtailing, among other things, an emerging "public" sexuality. Whether 
they called themselves "social hygienists," "progressives," "social feminists," or "social workers," their underlying aim was to preserve female purity standards associated with an earlier producer ethic. Amid the emerging polyglot of consumerism, Baldwin and other social hygienists sought to safeguard traditional morality by codifying and enforcing it through state intervention and interdiction. Although many of her rigid moral reasonings passed out of custom, Baldwin's true legacy survived in the thousands of women who have followed her professional footsteps. The complete integration of women into modern law enforcement became a living monument to the efforts that Portland's pioneer female officer inaugurated in the formative years of the twentieth century. 


\section{ABBREVIATIONS}

$C D$

LGB

LGB-FCS $/ 2118$

MOC

PARC

PPHS

TA

WPD/DAR
Council Documents

Lola G. Baldwin

Lola G. Baldwin Federal Civil Service

Form 2118 (biographic and work history)

Mayor's Office Correspondence

Portland Archives and Records Center

Portland Police Historical Society

Travelers' Aid

Women's Protective Division Daily Activity

Reports 
NOTES

PREFACE :

1. Raymond B. Fosdick, American Police Systems (1920; reprint, Montclair, N.J.: Patterson-smith, 1969), pp. 376, $376-7 n$. For other contemporary evaluations of the role of policewomen see Fosdick, et al, Criminal Justice in Cleveland: Cleveland Foundation Reports (1922; reprint, Montclair, N.J.: Patterson-Smith, 1968), pp. 25, 77, and Cornelius F. Calahane, The Policeman (1923; reprint, New York: Arno, 1970), p. $2 \overline{57 .}$

CHAPTER I :

1. Mary de Young, "Help, I'm Being Held Captive!: The White Slave Fairy Tale of the Progressive Era," Journal of American Culture, 6 (1983): 96-99; David J. Pivar, Purity Crusade: Sexual Morality and Social Control, $1868-1 \overline{900}$ (Westport, Conn.: Greenwood, 1973), pp. 176-7; E1 Ien M. Ewing, "Lola G. Baldwin, No. 1 Policewoman," Sunday Oregonian Northwest Living Magazine[NWL Mag.], $11 \mathrm{~J}$ une 1950, pp. 10, 14; "Its Work Needed," Oregonian, 16 April 1905 , p. 10; "Women Unite to Save Womankind," Oregon Journal, 16 April 1905, n.p., clipping in LGB file, PPHS; "For the Travelers' Aid," Oregonian, 11 June 1905, p. 9; For background on Jesse Honeyman see Helen Krebs Smith, ed., With Her Own Wings: Historical Sketches, Reminiscences, and Anecdotes of Pioneer Women, 2d ed (Portland, Oreg.: Beattie, 1974), pp. 235-237.

2. Oregonian, 16 April 1905, p. 10; Oregonian, 11 June 1905, p. 9; Ewing, Oregonian NWL Mag., 11 June 1950, pp. 10, 14; Biographical information from LGB-FCS/2118, copy in LGB file, PPHS; For a romanticized sketch of Baldwin see Smith, With Her Own Wings, pp. 231-234.

3. Carl Abbott, The Great Extravaganza, (Portland, oreg., 1981), quoted in E. Kimbark MacCol1, Merchants, Money, and Power: The Portland Establishment, 1843-1913, (Portland, oreg.: Georgian Press, 1988), pp. 383-4; Ro11a J. Crick, "Nation's First Women's Police Unit," Oregonian, 28 March 1954, p. 8a; "Will Close Up Massage Shops," oregonian, 21 May 1905, p. 8 . 
4. Ewing, Oregonian NWL Maq. , 11 June 1950, pp. 10, 14; Crick, oregonian, 28 March 1954, p. 8a; Oregonian, 16 April 1905, p. 10; "Home for Working Girls," oregonian, 10 June 1905, p. 9 .

5. Oregonian, 16 April 1905, p. 10; Ewing, Oregonian NWL Mag., 11 June 1950, pp. 10, 14; Crick, Oregonian 28

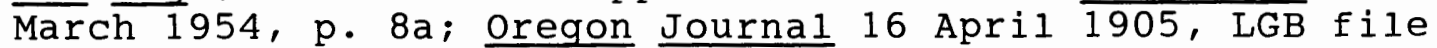
PPHS.

6. Oregonian 21 May 1905, p. 8; "Juvenile Court First Session," Oregonian, 10 June 1905, p. 5; LGB Commission of Probation Officer for Juvenile Court, 10 June 1905, copy in LGB file PPHS; LGB-FCS/2118, LGB file PPHS.

7. LGB-FCS/2118, LGB file PPHS; "City's First

Policewoman, 97, Dies," Oregon Journa1, 24 June 1957, p. 6; "Death Takes Mrs. Baldwin," Oregonian, 24 June 1957, p. 13; Two Birthdays, Golden Wedding Date Celebrated," Oregonian, 30 December 1934, p. 16.

8. Estelle B. Freedman, Their Sister's Keepers: Women's Prison Reform in America, 1830-1930 (Ann Arbor, Mich.: University of Michigan Press, 1981), pp. 35n, 198; Pivar, p. 154; For a contemporary portrait of a rescue home see Kate Waller Barrett, Some Practical Suggestions on the Conduct of

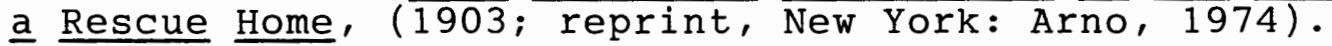

9. LGB-FCS/2118, LGB file PPHS.

10. "For Travelers' Aid," Oregonian, 13 August 1905, p. 14; "For a Clean Town," oregonian, 9 July 1905, p. 11; LGB to Harry Lane, $14 \mathrm{July}$ 1905, copy in MOC 1905, Box 1, File $1 / 2,15-07-31 / 1$, PARC.

11. Louise Bryant, "Portland Pioneer in Municipal Protective Work for Women, oregonian, 14 January 1912, p. 5; "For Travelers' Aid," Oregonian, 13 August 1905, p. 14. p. 14 .

12. "For Travelers' Aid," Oregonian, 20 October 1905 ,

13. "Girls Are In Need," Oregonian, 25 October 1905, p. 10; LGB to Harry Lane, 30 December 1905, copy in MOC 1905, Box 1, File 1/2, 15-07-31/1, PARC.

14. LGB to Harry Lane, 30 December 1905; "Travelers' Aid is Disbanded," Oregonian, 26 January 1906, p. 14; "Travelers' Aid Will Celebrate Golden Jubilee, "Oregonian, 17 April 1955, sec. 3, p. 9; For Rabbi Wise's expectations for the interdenominational effort see Oregonian, 16 April 1905, p. 10; LGB Complete Report of TA Vice Work 1905-1907, 
December 1907, copy in MOC 1908, Box 13, File 13/7, 15-07-25, PARC; LGB Synopsis of TA Work, 1905 through October 1907, copy in MOC 1907, Box 8, File 8/17, 15-07-34/1, PARC.

15. LGB TA Synopsis 1905-1907; YWCA TA 1907 Activity Log, [partial], copy in MOC 1908, Box 11, File 11/2, 15-07-33/3, PARC.

16. LGB FCS/2118, LGB file PPHS; LGB TA Synopsis 1905-1907; LGB Complete TA Report 1905-1907; LGB Report of the San Francisco Relief Fund, copy in MOC 1908, Box 11 , File $11 / 3,15-07-33 / 3$, PARC.

17. LGB TA Synopsis 1905-1907; LGB Complete TA Report 1905-1907.

18. LGB Complete TA Report 1905-1907.

19. Ibid.

20. Ibid.; "\$3,000 From City to Travelers' Aid," Oregonian, 24 December 1907 , p. 11 .

21. Portland Ordinances 17410 and 17411 , Copies in MOC 1908, Box 12, File 12/3, 15-07-34/3, PARC; "Votes Money to YWCA," Oregonian, 13 February 1908, p. 5; LGB to Mayor and City Council, 8 February 1908, copy in MOC 1908, Box 13, File 13/7, 15-07-25, PARC.

22. Ordinances 17410 and 17411; Oregonian, 13 February 1908, p. 5; Civil Service Commission to LGB, 11 March 1908, copy in LGB file, PPHS; LGB WPD/DAR 1 April 1908, PPHS.

23. MacColl, pp. 372-389; Pivar, p. 131 .

24. MacCol1, pp. 382, 389; For a portrait of Sarah Evans see Smith, With Her Own Wings, pp. 229-30; For an overview of the medical alarm over prostitution see John C. Burnham, "The Progressive Era Revolution in American Attitudes Toward Sex," Journal of American History 59 $(1973)$ : 886, 892-895 and John D'Emilio and Estelle B. Freedman, Intimate Matters: A History of Sexuality in America, (New York: Harper and Row, 1988), p. 204; "Doctors Will Visit Portland," Oregonian, 9 July 1905, p. 8.

25. D'Emilio and Freedman, p. 204; Burnham, p. 888; "For a clean Town," Oregonian, 9 July 1905, p. 11 .

26. MacColl, pp. 391-392; Captain P. Bruin to Chief Gritzmacher, 2 July 1906, copy in MOC 1906, Box 5, File 5/3, 15-07-31/3, PARC; Captain P. Bruin to Mayor Lane, 17 January 1908, copy in MOC 1908, Box 12, File 12/3, 15-07-34/3, PARC. 
27. Oregonian, 9 July 1905, p. 11; MacColl, p. 437; WPD/DAR 22 JulY 1908; LGB Complete TA Report 1905-1907; Louise Aaron, "Mrs. Baldwin Feted on 88th Birthday," Oregon Journal, 31 January 1948, p. 1; Ewing, Oregonian NWL Mag.' 11 June 1950, pp. 10, 14.

28. Ewing, Oregonian NWL Maq., 11 June 1950, pp. 10, 14; Samuel Walker, A Critical History of Police Reform: The Emergence of Professionalism (Lexington, Mass.: D. C. Heath, 1977), p. 86; Pivar, pp. 154, 166, 176; LGB Complete TA Report 1905-1907.

29. Rosalind Rosenberg, Beyond Separate Spheres: The Intellectual Roots of Modern Feminism (New Haven: Yale University Press, 1982 ), xiii-xiv; Pivar, pp. 6, 171, 262, 274; William L. O'Neill, The Progressive Years: America Comes of Age (New York: Harper and Row, 1975), pp. 81-82.

30. Pivar, p. 258; 0'Neill, pp. 81-82; Don S.Kirschner, The Paradox of professionalism: Reform and Public Service in Urban America, 1900-1940 (New York: Greenwood Press, 1986), pp. xi, 2 . 


\section{CHAPTER II :}

1. LGB to Harry Lane, cover letter to Complete TA Report, 1905-1907, copy in MOC 1908, Box 13, File 13/7, 15-07-25, PARC; LGB to Chief Gritzmacher and Captain Baty, 1 May 1908, copy in MOC 1908, Box 12, File 12/3, 15-07-34/3, PARC; Personal interview with Sgt. Ralph O'Hara, curator, PPHS, January, 1991; Pivar, pp. 154, 159, 176.

2. WPD/DAR 17 February 1909; LGB to Gritzmacher and Baty, 1 May 1908.

3. Kathy Peiss, Cheap Amusements: Working Women and Leisure in Turn-of-the Century New York (Philadelphia: Temple University Press, 1986), pp. 5, 6, 45; Lewis A. Erenberg, Steppin' Out: New York Nightlife and the Transformation of American culture (Chicago: University of Chicago Press, 1984), pp. xiv, 5, 6, 61; Lary May, Screening Out the Past: The Birth of Mass Culture and the Motion Picture Industry (New York: Oxford University Press, 1980), p. 38 .

4. D'Emilio and Freedman, pp. 195-200, 203-204, 208-210; WPD/DAR entries on Portland amusements, various dates, $1908-1913$.

5. Peiss, pp. 5, 6; May, p. 46; Erenberg, pp. 5, 6, 66.

6. Erenberg, pp. xii, 5, 6, 64; LGB to Harry Lane, 25 November 1908, Copy in MOC 1908, Box 12, File 12/3, 15-07-34/3, PARC; "Dancehal1 is Closed," Oregonian, 24 February 1910, p. 4; "Dance Halls Evil," Oregonian, 28 February 1910, p. 16; WPD/DAR 22 June 1909.

7. Report of Committee on Health and Police, 9 March 1910, copy in CD 1910, Box 107, File 107/12, 19-04-15/2, PARC; For character of nineteenth-century dance halls see Peiss, p. 96, May, p. 49 and D'Emilio and Freedman, pp. 130, 195, 199, 208; "Many Girls Aided," Oregonian, 14 October 1908, p. 16; WPD/DAR 22 June 1909; LGB Annual Report 1909, copy in MOC 1909, Box 24, File 24/6, 15-07-28/3, PARC; Oregonian 28 February 1910, p. 16; Deposition "State vs. Wroten" (Club Saloon), copy in CD 1908, Box 99, File 99/6, 19-04-13/1, PARC; LGB to Harry Lane, 25 November 1908. 
8. For general background on these dance steps, see Peiss, pp. 45, 100-104, Erenberg, pp. 73-74, 151-155 and D'Emilio and Freedman, p. 196; Oregonian, 28 February 1910 , p. 16; WPD/DAR 2 November 1910 ; Report of Committee on Health and Police, 9 March 1910; "Shocking Dances," oregonian, 22 February 1910, p. 20 .

9. Report of Committee on Health and Police, 9 March 1910; Erenberg, pp. 63, 64, 81; Peiss, pp. 45, 88-89; D'Emilio and Freedman, pp. 130, 195, 199, 208.

10. May, p. 49; Peiss, p. 95; Chief Gritzmacher to Mayor Lane, 27 May, 1909, copy in MOC 1909, Box 17, File 17/5, 15-07-25, PARC; Oregonian, 28 February 1910, p. 16; WPD/DAR : 13, 16, 23, 25 June 1908, 25 February 1909.

11. LGB to Chief Gritzmacher, 1 June 1908, copy in MOC 1908, Box 12, File 12/3, 15-07-34/3, PARC; MaY, p. 52;

"Mayor to Raid Dances," oregonian, 23 February 1910, p. 11; "Mayor is opposed by Mrs. Baldwin," Oregonian, 27 February 1910, p. 10; Oregonian 28 February 1910, p. 16; "Mrs Baldwin to be Reprimanded," Oregonian, 1 March 1910, p. 10; "Expenses of Mrs. Baldwin Held Up," Oregonian, 2 March 1910, p. 12; "Inquiry is Held Today," Oregonian, 3 March 1910, p. 12 .

12. "In Place of Dancehalls?," Oregonian, ed., 1 Mar. 1910, p. 6; Oregonian 28 February 1910, p. 16; Report of Committee on Health and Police, 9 March 1910;

13. Oregonian 28 February 1910, p. 16; A. DuChamp to License Committee, 3 september 1912, copy in CD 1912, Box 119, File 119/11, 19-04-14/1, PARC; Remonstrance Against Dance on Portland Heights, copy in CD 1909, Box 102, File 102/7, 19-04-14/1, PARC; "Dancehall to Go," Oregonian, 26 May, 1910, p. 4; LGB to Joseph Simon, 10 January 1911, copy in MOC 1911-12, Box 24, File 24/6, 15-07-28/3, PARC.

14. WPD/DAR: 23 September, 16 October, 15 December 1911,4 January, 13 April, 24, 28, 29 June, 28 July, 19, 21 November 1912, 5 March, 8 May, 11 July 1913; A DuChamp to License Committee, 3 September 1912; Ordinance 27553, Regulating Dancing and Dance Halls, 13 August 1913, copy in MOC 1916, Box 38, File "Dance Matters," 15-07-14/1, PARC; "Public Dancing is Regulated by Act," Oregonian, 27 March 1913 , p. 20.

15. Ordinance 27553, 13 August 1913; LGB "Status and Experience," n.d., copy in LGB file PPHS; LGB to Mayor Baker, 16 March 1922, copy in MOC 1922, Box 38, File "Dance Matters," 15-07-14/1, PARC; "Drastic Dance Law is Asked In New York," Oregonian, 13 March 1922, p. 4. 
16. Erenberg, pp. xii, 63; Peiss, p. 162; May, p. 46.

17. Erenberg, pp. 67, 69, 177-178, 194; Peiss, pp. 144-145.

18. WPD/DAR 2 November 1910; "Act is Protested," Oregonian, 5 November 1910, p. 5; "Singer's Act is Abruptly Ended," Oregonian, 6 November 1910, sec. 1, p. 12; Erenberg, p. 193 .

19. "Singer's Ire is Up," Oregonian, 7 November 1910,

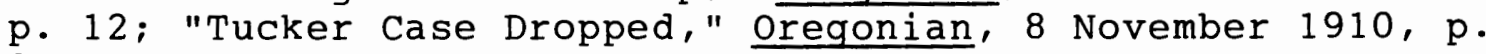
9 .

20. Ibid.

21. Ibid.

22. Ibid.; LGB to Mayor Simon, 10 January 1911 , copy in MOC 1911-12, Box 24, File 24/6, 15-07-28/3, PARC.

23. Oregonian, 6 November 1910 , p. 12; Erenberg, pp. $187-197$.

24. "First Moving Pictures in Portland," oregonian, 5 August 1897 , p. 10; Erenberg, pp. 69, 70; May, pp. 26, 27; Robert Sklar, Movie-Made America: A Cultural History of American Movies (New York: Vintage Press, 1976), pp. 4,5 .

25. WPD/DAR: 27 April 1908, 19 May, 28 August, 9 November 1909, 22 February 1910, 11 March 1911.

26. WPD/DAR: 11 March, 23 September 1911; Mayor H. R. Albee to L. L. Lewis, 5 March 1914, copy in MOC 1914, Box 30, File 30/7, 15-07-20/3, PARC; "Municipal Board of Review" entry, Card-file/ Historical Index, 2012-10 2/2, PARC.

27. "Children and the City streets at Night," Oregon Social Hygiene Society Report, copy in MOC 1914, Box 31, File 31/8, 15-07-21/1, PARC; Oregon Congress of Mothers and Parent-Teacher Associations to Mayor Albee, 27 March 1914, copy in MOC 1914, Box 31, File 31/8, 15-07-21/1, PARC; Mayor Albee to C. Lindsay, 13 November 1914, copy in MOC 1914, Box 30, File 30/8, 15-07-20/3, PARC; For a resume of BaIdwin's thoughts on the declining authority of families see LGB to Mayor and Chief, 6 February 1922, copy in LGB file PPHS.

28. Erenberg, p. 72; May, p. 59; "Children and the City Streets at Night"; WPD/DAR 20 February, 7 october 1913.

29. Peiss, pp. 185-188; Erenberg, pp. 5-6; Clifford G. Roe, The Prodigal Daughter: The White Slave Evil and the 
Remedy, quoted in Pamela Ann Roby, "Politics and Prostitution: A Case Study of the Formulation, Enforcement, and Judicial Administration of the New York State Laws on Prostitution, 1870-1970," Ph.D. diss., New York University, 1971, p. 135 . 
CHAPTER III :

1. Steven Schlossman and Stephanie wallach, "The Crime of Precocious Sexuality: Female Juvenile Delinquency in the Progressive Era," Harvard Educational Review, 48 (February 1978): 69-72. For an early example of Baldwin's involvement with the Conference of Charities and Corrections see WPD/DAR: 12,13 October 1908.

2. Schlossman and wallach, "Precocious Sexuality," Harvard Ed. Rev., pp. 72-77; "Its First Session," Oregonian, 10 June 1905, p. 5; "Portiand Court a Model," Oregonian, 24 April 1907, p. 10; General Laws of Oregon 1907, Chapter 34, pp. 39-47; Genera1 Laws of Oregon 1913, Chapter 153, pp. 268-270; WPD/DAR: 16 February, 7 May 1913.

3. LGB Complete TA Report, 1905-1907; WPD/DAR 21 July 1909; WPD/DAR: 13 October, 28 November 1908.

4. WPD/ DAR: 5, 7, 16, 27 November 1908; For a description of George Chamberlain's early social hygiene work see "Pioneer Experiences," Social Hygiene, 5, 4 (October 1919): 585 .

5. WPD/DAR 4 February 1909; Schlossman and Wallach, "Precocious Sexuality," Harvard Ed. Rev., p. 80.

6. Portland Vice Commission, Third Report of the portland Vice Commission, December 1912, pp. 95-97. Of 1504 women arrested on morals charges between January 1911 and June 1912, 60 percent were reported as "American," 11.6 percent "Negro," but only 5.9 percent were Eastern or Southern Europeans; D'Emilio and Freedman, p. 215.

7. WPD/DAR: 11 May, 18 Apri1 1908, 24, 29 March 1911, 27 January, 6 March, 30 June, 25 November, 4 December 1912, 7 February 1913; LGB to Mayor Albee, 7 February 1914, Copy in MOC 1914, Box 61, File 61/1, 15-07-01/1, PARC; D'Emilio and Freedman, p. 215.

8. Portland's NAACP estimated 2,500 African-Americans in a general urban population of about 250,000. See Portland Chapter NAACP to Mayor Albee, 12 July 1915, Copy in MOC 1915, Box 49, File 49/5, 15-07-07/1, PARC; For a brief summation of the 1908 formation of the NAACP see David W. Noble, The progressive Mind, 1890-1917, (Minneapolis: 
Burgess, 1981), pp. 127-128; D'Emilio and Freedman, pp. 202-203; WPD/DAR: 1, 6, 19 November, 5, 6, 7 December 1912, 6,18 January 1913 .

9. LGB to Mayor Albee, 26 November 1913, copy in MOC 1913, Box 61, File 61/1, 15-07-01/1, PARC.

23.

10. D'Emilio and Freedman, pp. 203, 215; 0'Nei11, p.

11. D'Emilio and Freedman, p. 174; WPD/DAR: 12 May, 1 December 1908, 7 June, 5 November 1909, 13 January, 2, 15 September 1910 .

12. Lord's oregon Laws, Section 1900, p. 862; WPD/DAR: ["abortion" entries,] 15 May, 23 July 1908, 6, 15 January, 24 February, 23 March, 9 June, 26 July, 1 August, 24 october 1909, 28 January, 22 February, 15 July, 2, 15 September, 15 October 1910, 26 August 1911, 20 August, 12, 17 October 1912 .

13. WPD/DAR: 13 January, 9 June 1909, 15 september 1910,17 October 1912 .

14. WPD/DAR: 24-31 October, 20 November 1909 .

15. WPD/DAR: 15 January, 2, 3 February 1909, 5 october 1910; General Laws of Oregon, 1909, p. 229; LGB Annual Report for 1910, copy in MOC 1911-12, Box 24, File 24/6, 15-07-28/3, PARC.

16. WPD/DAR: 23 JuIy 1908, 6 January, 24 February, 26 July 1909, 15 September 1910, 20 August 1912.

17. William T. Foster, ed. The Social Emergency: Studies in Sex Hygiene and Morals (Boston: Houghton-Mifflin, 1914), pp. 37-39. Head of the oregon Social Hygiene Society and president of Portland's Reed College, Foster was well known in national social hygiene circles.; "Case History of Lillian L.," 13 November 1913, copy in MOC 1913, Box 61, File 61/1, 15-07-01/1, PARC; WPD/DAR: 5 October 1908, 7 June, 19 July, 15, 29 August 1909.

18. WPD/DAR: 15 December 1911, 12 February, 22 June 1912; For local homes delinquent girls were remanded to see W. T. Gardner, Boys and Girls Aid Society of Oregon, to Mayor H. R. Albee, 12 November 1913, copy in MOC 1915, Box 33, File 33/3, 15-07-21/2, PARC.

19. D'Emilio and Freedman, pp. 195-200; James J. Flink, The Automobile Age (Cambridge, Mass.: M I T Press, 1990), p.160.; Howard B. Woolston, Prostitution in the 
United States (1921; reprint, Montclair, N.J.:

Patterson-Smith, 1969), p. 153,4; WPD/DAR: 7, 19 June, 29 August 1909, 30, 31 March 1910, 16 April, 18 June 1912; LGB Six Month Report to Mayor Simon, 1 July 1909, copy in MOC 1909, Box 24, File 24/6, 15-07-28/3, PARC; LGB to Mayor Albee, 27 February 1915, copy in MOC 1915, Box 61, File $61 / 2,15-07-01 / 1$, PARC.

20. Woolston, p. 70. A quarter of Woolston's sample of young early twentieth-century prostitutes implicated alcohol in their downfalls.; LGB Report of Women's Auxiliary, August 1908, copy in CD 1908, Box 101, File 101/1, 19-04-13/2, PARC; LGB Six Month Report to Mayor Simon, 1 July 1909; WPD/DAR 3 JUlY 1908.

21. Ruth B. Moynihan, Rebel for Rights: Abigail Scott Duniway (New Haven: Yale University Press, 1983), pp. 212-219; General Laws of Oregon, 1907, pp. 39-47, 154-5.

22. LGB to Chief Gritzmacher, 1 June 1908 and LGB to Mayor Lane, 25 November 1908, copies in MOC 1908, Box 12, File 12/3, 15-07-34/3, PARC; WPD/DAR: 11 MaY, 3, 7, 18, 22 July, 10, 25 August 1908 .

23. Transcript "State vs. Wroten," copy in CD 1908, Box 99, File 99/6, 19-04-13/1, PARC; WPD/DAR: 26 August, 8, 14, $21,22,23,24$ September 1908, 8 March 1909.

24. WPD/DAR: 8 March, 13 April, 18 June 1909, 15 December 1911 .

25. WPD/DAR: $28 \mathrm{May}, 2,22$ June, 26 July 1909.

26. LGB Annual Report 1911, in Mayor's Message and Annual Reports 1911, pp. 538-539, Box 27, Fi ie 2012-35, 17-06-02, PARC; WPD/DAR 4 January 1912; LGB to Mayor Rushlight, 13 March 1912, copy in CD 1912, Box 121, File $121 / 6$, 19-04-09/2, PARC.

27. Vice Commission to Mayor and Council, 5 April 1912, copy in MOC 1912, Box 25, File 25/21, 15-07-19/1, PARC; Portland Ordinance 25477, 26 June 1912, copy in CD 1912, Box 120, File 120/2, 19-04-10/1, PARC.

28. Schlossman and Wallach, "Precocious Sexuality," Harvard Ed. Rev. , pp. 75-78.

29. WPD/DAR: 8 February, 12 December 1912, 15 January, 16 February, 1, 7, 23 May, 5, 11 June 1913; LGB to Police Committee of City Council, 31 January 1912, copy in CD 1912, Box 122, File 122/3, 19-01-10/2, PARC; LGB to Mayor Albee, 15 July 1913, copy in MOC 1913, Box 61, File 61/1, 
15-07-01/1, PARC; General Laws of oregon 1913, Chapter 153, pp. 268-270; Estelle B. Freedman, Their sisters' Keepers: Women's Prison Reform in America, 1830-1930 (Ann Arbor, Mich.: University of Michigan Press, 1981), p. 131. 30. Genera1 Laws of Oregon 1913, Chapter 153, pp. 268-270; LGB to Mayor A1bee, 2 August 1915, copy in MOC 1915, Box 61, File 61/3, 15-07-01/1, PARC.

31. Mayor Albee to LGB, 3 August 1915, copy in MOC 1915, Box 61, File 61/3, 15-07-01/1, PARC.

32. Freedman, p. 130; Baldwin placed 295 of the 460 on the "after care" 1ist, while 26 were noted as being officially "on parole." See LGB Annual Report 1909, copy in MOC 1911, Box 24, File 24/6, 15-07-28/3, PARC; WPD/DAR 15 December 1911; LGB Annual Report 1911, in Mayor's Message and Annual Reports 1911, Box 27, 17-06-02, PARC; LGB to Chief of Police and Captain Baty, 1 May 1908, copy in MOC 1908, Box 12, File 12/3, 15-07-34/3, PARC.

33. For more detail of the Progressive Era's changes in women's penal institutions, see Freedman, pp. 131-147. 
CHAPTER IV :

1. John C. Burnham, "The Progressive Era Revolution in American Attitudes Toward Sex," Journal of American History 59 (1973): 885-908; Foster, pp. 5-12; David W. Noble, The Progressive Mind, 1870-1917 (Minneapolis: Burgess, 1981), p. 85 .

2. Foster, pp. 5-12; Burnham, "Progressive Attitudes," Jour. Am. Hist., pp. 884-885.

3. Foster, pp. 13-24; Burnham, "Progressive Attitudes," Jour. Am. Hist., p. 886; D'Emilio and Freedman, pp. 206-208; "Anti-Vice Body OutIines Labors," Oregonian, 21 september $1911, \mathrm{p} .4$.

4. Oregonian, 21 September 1911, p. 4; WPD/DAR: 8 August, 29 September, 5 October 1908, 15, 16 January 1909, 6 November, 15 December 1911; Raymond B. Fosdick, "The Annual Report of the Commission on Training Camp Activities," Social Hygiene 5, no. 2 (Apri1 1919), 267.

5. Ruth Rosen, The Lost Sisterhood: Prostitution in America, 1900-1918 (Baltimore: Johns Hopkins, 1982), xi-xiv; D'Emilio and Freedman, pp. 209-210.

6. MacCo11, pp. 372-397; "Will Close Up Massage Shops," oregonian, 21 May, 1905, p. 8.

7. For a contemporary description of Portland's North End see District Attorney to James B. Reynolds, 15 April 1914, copy in MOC 1914, Box 29, File 29/9, 15-07-19/3, PARC; MacColl, p. 392; Captain Bruin to Chief Gritzmacher, 2 July 1906, copy in MOC 1906, Box 5, File 5/3, 15-07-31/3, PARC; Woolston, p. 104n; "Pitfalls for Girls," oregonian, 5 March 1907, p. 11; WPD/DAR: 13 Apri1, 7 October 1908 .

8. LGB Six Month Report to Mayor Simon, 1 July 1909; D'Emilio and Freedman, pp. 209-210; LGB FCS/2118, LGB file PPHS; LGB Annual Report for 1910, Copy in MOC 1911, Box 24, File 24/6, 15-07-28/3, PARC; WPD/DAR: 13-25 Apri1, 7

September $1908,16,29$ June 1909, 13 January 1912.

9. WPD/DAR 7 september 1908 . 
10. Captain P. Bruin to Mayor Lane, 17 January 1908, copy in MOC 1908, Box 12, File 12/3, 15-07-34/3, PARC; WPD/DAR 13 April 1909; Anti-prostitution petitions to Mayor Lane [numerous], September 1908, copies in MOC 1908, Box 12, File 12/3, 15-07-34/3, PARC; MacCol1, p. 392. Although MacColl has suggested that the merchants who signed these anti-prostitution remonstrances were primarily concerned with improving conditions near their businesses, the actual petition letters made no mention of this and were very carefully couched in social hygiene language.; Rosen, pp. 14-19; Pivar, p. 154 .

11. WPD/DAR: 7 December 1908, 27 January, 13 April 1909,15 December 1911 .

12. MacCol1, pp. 419-20; WPD/DAR: 19, 26, 28 May, 1, 2 June 1909; "Will Close Up Massage Shops," Oregonian, 21 May, 1905, p. 8.

13. WPD/DAR: 26 May, 1, 18 June 1909.

14. LGB Six Month Report to Mayor Simon, 1 July 1909; LGB recounted her battle against the massage parlors to Mayor Albee several years later. See LGB to Mayor Albee, 3 July 1913, copy in MOC 1913, Box 61, File 61/1, 15-07-01/1, PARC; WPD/DAR: 21, 22, 29 June, 5 July 1909.

15. "Provide $\$ 267,745$ for Police Work," Oregonian, 21 January 1909, p. 10; MacColl, pp. 418, 432-34; LGB Six Month Report to Mayor Simon, I July, 1909; WPD/DAR: 13, 14, 27 January, 1, 10 February, 1 March 1909; "Charter Changes Number Twelve," Oregonian, 9 June 1909, p. 18.

16. WPD/DAR: 1-15 August, 1 September, 5 september-17 october 1909; LGB to Mayor Simon, 4 September 1909, copy in MOC 1911, BOX 24, File 24/6, 15-07-28/3, PARC; Report of Health and Police Committee, 17 September 1909, copy in CD 1911, Box 102, File 102/7, 19-04-14/1, PARC.

17. MacCo11, p. 418; Rosen, pp. 14-19; Pivar, p. 154; "Bad Zone Best Plan," Oregonian, 27 October 1909, p. 4.

18. Oregonian, 27 october 1909, p.4; LGB to Mayor Simon, 28 October 1909, copy in MOC 1911, Box 24, File 24/6, 15-07-28/3, PARC; Simon's remarks appeared in a story reporting other matters as well. See "Mayor Stands by Pact on Boxing," Oregonian, 28 october 1909, p. 16; "Agrees With Mayor Simon," Oregonian, 29 october 1909, p. 20.

19. "Calls on Mayor Simon," Oregonian, 29 October 1909, p. 20.; Otto Wilson, Life of Dr. Kate Waller Barrett (1933; reprint, New York: Arno, 1974), p. 178 . 
20. LGB to Mayor Simon, 28 October 1909; Estelle B. Freedman, Their Sister's Keepers: Women's Prison Reform in America, 1830-1930 (Ann Arbor, Mich.: University of Michigan Press, 1981), p. 127.

21. Chicago Law and Order League Report, and 1910 New York Grand Jury White Slave Traffic Report, with cover letter LGB to Mayor Simon, 27 February 1911, copies in MOC 1911, Box 24, File 24/6, 15-07-28/3, PARC; D"Emilio and Freedman, p. 210 .

22. For Oregon's "Little Mann Act" see General Laws of Oregon, 1911, Chapter 68, pp. 107-108; WPD/DAR: 12 October, 20 November $1910,25 \mathrm{March}, 15,25$ June, $26 \mathrm{Ju} 1 \mathrm{y}, 19$ August, 17 October 1911, 13 January, 8 February, 16 Apri1, 4, 13, 18, 19 June, 18 July, 19 November, 16, 18, 19 December 1912 .

23. MacCo11, pp. 433-434; Rosen, pp. 14-15.

24. "Badland Not to be Segregated," Oregonian, 6 July 1911 , p. 12; WPD/DAR 24 July 1911.

25. "Vice Commission Asked," Oregonian, 23 August 1911, p. 11; "Social Evil is Study," Oregonian, 28 August 1911, p. 11; "15 to Down Vice," Oregonian, 30 August 1911, p. 11; "Rushlight Names Vice Commission," 24 september 1911, sec. 2 , p. 22 .

26. "Vice Report Made," Oregonian, 10 January 1912, p. 12; Portland Vice Commission First Report, January 1912, pp. $4-6$; WPD/DAR 21 July, 1 september 1909.

27. "Citizens Baffled by Vice Problem," Oregonian, 21 July 1912, p. 18; LGB to Chief Slover, 26 June 1912, copy in CD 1912, Box 122, File 122/3, 19-04-10/2, PARC.

28. Oregonian 21 July 1912 , p. 18 .

29. "Portland Immoral, Vice Prober's Say," Oregonian, 23 August 1912 , pp. 1, 4, 6; MaCCo11, pp. 534-538; Portland Vice Commission second Report, August 1912, pp. 71-75.

30. WPD/DAR: 13 April 1909, 15 December 1911; Portland Vice Commission Third Report, December 1912, pp. 84-108; For a contemporary assessment of the abatement code question see Bascom Johnson, "The Injunction and Abatement Law," Social Hygiene 1, no. 2 (March 1915): 231-256.

31. Third Report, pp. 109-115; MacCo11, pp. 445-449.

32. MacColl, 436-438, 448; Third Report, passim. 
33. Joseph Mayer, "The Passing of the Red Light District," Social Hygiene 4, no. 2 (April 1918): 197-209; Paul B. Johnson, "Social Hygiene and the War," Social Hygiene 4, no. 1 (January 1918): 197-209; Mayor's office copy of social hygiene pamphlet "Single Men in Barracks," Frank P. Stockbridge editor, undated, copy in MOC 1918, Box 38, File 38/20, 15-07-14/1, PARC; Jane D. Rippin, "Social Hygiene and the War: Work with Women and Girls," Social Hygiene 5, no. 1 (January 1919): 125-127.

34. Katherine B. Davis, "Social Hygiene and the War: Women's Part in Social Hygiene," Social Hygiene 4, no. 4 (October 1918), 532-33; Rippin, 126-27; Stockbridge, passim; "Federal Position is Given Mrs. Baldwin," Portland Evening Telegram, 9 February 1918, p. 17; Jane Addams had warned about moral danger to girls near military camps as early as 1912. See Jane Addams, A New Conscience and an Ancient Evil (New York: MacMillan and Co., 1912), pp. 200-203.

35. "Mrs. Lola Baldwin Called for War Work," Oregonian, 7 February 1918, p. 9; "Police Matron Gets Fosdick Commission," Oregon Journal, 9 February 1918, p. 7; Portland Civil Service Board to Mayor George Baker, 13 December 1918 , copy in MOC 1918, Box 45, File 45/14, 15-07-15/2, PARC; Portland Ordinance 33646, 2 January 1918, "Detention Home for Women," and Portland Ordinance 33649, 2 January 1918, "Hotels, etc.," copies in Council ordinances 1917-18, Box 32821-34249, File 95, 05-01-54, PARC; Portland Ordinance 33853, 27 February 1918, "Solicitation," copy in Council Ordinances 1917-18, Box 32821-34249, File 102, 05-01-54, PARC; Portland Ordinances 33950, 27 March 1918, "Women's Protective Division," and Ordinance 33964, 3 April 1918, "Women's Protective Division," copies in Council ordinances 1917-18, Box 32821-34249, File 105, 05-01-54, PARC.

36. Rippin, "Women and Gir1s," Soc. Hyg., pp. 125-136; Rosen, p. 35; M. C. Greegor to LGB, 10 August 1918 , copy in LGB file, PPHS.

37. Rippin, "Women and Girls," Soc. Hyg. , p. 135; LGB FCS/2118, LGB file, PPHS; WPD/DAR 13 February 1913; LGB Report of 7 th District for December, 1918, copy in LGB file, PPHS; Mayor George Baker to Committee for Civilian Cooperation in Combating Venereal Disease, 12 March 1918, copy in MOC 1918, Box 68, File 68/7, 15-07-04/1, PARC.

38. Jane D. Rippin to LGB, 5 December 1918 , copy in MOC 1918, Box 45, File 45/14/15-07-15/2, PARC.; Raymond B. Fosdick, "Annual Report of the Commission on Training Camp Activities, 1919," Social Hygiene 5, no. 2 (April 1919): 267; LGB FCS/2118, LGB file, PPHS; Rosen, pp. 36-37. 

$35-37$.

39. D'Emilio and Freedman, pp. 211-215; Rosen, pp.

40. LGB files, passim.

41. For the totalitarian aspects of World War I anti-prostitution activities, see David J. Pivar, "Cleansing the Nation," Prologue 12 (Spring 1980): 29-40, and Roy Lubove, "The Progressives and the Prostitute," The Historian 24 (May 1962): 308-330. 
CHAPTER V:

1. "Lola Baldwin Will Take Old Police Place," Portland Evening Telegram, 6 December 1920, p. 3; "Big Shakeup Due in Police Bureau," Oregonian, 6 December 1920, pp. 1, 5; For letters on the Tazewel1-Frankel dispute, see Tazewell to Baker, 18 September 1918; Frankel to Johnson, 21 September 1918; Baker to Tazewe11, 3 October 1918; Johnson to Baker, 5 October 1918; Tazewe11 to Baker, 21 December 1918; Frankel to Johnson, 27 December 1918; Tazewell to Baker, 9 January 1919; Baker to Johnson, 15 January 1919; Moorad to Johnson, 17 January 1919; Johnson to Baker, 21 January 1919. copies in MOC 1918-19, Box 62, Files 62/15 and 62/16, 15-07-02/1, PARC.

2. LGB to Mayor and Chief of Police, 6 February 1922, copy in LGB file, PPHS; "Public Weddings Rapped," Oregonian, 6 November 1921 , Sec. 1, p. 10.

3. "Flappers Flit to Doom, Says Chief of Police Bureau," Oregonian, 6 February 1922, n.p., newsclipping in LGB file, PPHS; LGB to Mayor and Chief, 6 February 1922 .

4. Ibid; For a comprehensive study of 1920s youth see Paula S. Fass, The Damned and the Beautiful: American Youth in the 1920s (New York: Oxford University Press, 1977).

5. "Lola G. Baldwin Quits Police Job," Oregonian, 30 April 1922, p. 16; Ewing, Oregonian NWL Mag. , 11 June 1950 , pp. 10, 14; Freedman, p. 149; "City's First Policewoman, 97, Dies," Oregon Journal, 24 June 1957, p. 6; "Death Takes Mrs. Baldwin," Oregonian, 24 June 1957, p. 13.

6. Robert Liebman and Michael Polen, "Perspectives on Policing in Nineteenth-Century America," Social Science History 2, 3 (Spring 1978): 352-359.

7. Don S. Kirschner, The Paradox of Professionalism: Reform and Public Service in Urban America, 1900-1940 (New York: Greenwood Press, 1986), PP. 53-55.

8. For overviews of the activities of urban female purity workers during the Progressive years, see Pivar, Purity Crusade, pp. 176-77, 255-277, and Noble, Chapter 5; For middle-class fears about changing morality, see D"Emilio and Freedman, pp. 214-15. 
9. Liebman and Polen, "Perspectives," Soc. Sci. Hist., p. 356; WPD/DAR: 8, 9 April 1913; H. R. Albee to LGB, 29 October, 1914, copy in MOC 1914, Box 61, File 61/1, 15-07-01/1, PARC.

10. LGB to H. W. Wallace, 21 November 1912, and E. A. Slover to Ways and Means Committee, 21 November, 1912, copies in CD 1913, Box 127, File 127/10, 19-04-01/1, PARC; LGB to Mayor and Chief of Police, 6 February 1922, copy in LGB file, PPHS.

11. Freedman, pp. 126-130; Ewing, Oregonian NWL Maq., 11 June 1950, pp. 10, 14; LGB to E. A. Slover, 21 June 1912, copy in CD 1912, Box 122, File 122/3, 19-04-10/2, PARC.

12. Kirschner, xi.

13. Chloe Owings, Women Police: A Study of the Development and Status of the Women Police Movement (1925; reprint, Montclair, N.J.: Patterson-Smith, 1969); For examples of some recent police histories which rely heavily on Owings' work, see Gerald E. Caiden, Police Revitalization (Lexington, Mass.: D. C. Heath, 1977), p. 136; Samuel Walker, Popular Justice: A History of American Criminal Justice (New York: Oxford University Press, 1980), p. 132; Elizabeth S. Smith, Breakthrough: Women in Law Enforcement (New York: Walker, 1982), p. 5; Susan Erlich Martin, Breaking and Entering: Policewomen on Patrol, (Berkeley and Los Angeles: University of California Press, 1980), p. 21; Peter Horne, Women in Law Enforcement (Springfield, Il.: Thomas, 1980), pp. $22-28$.

14. LGB to H. R. Albee, 24 June 1913, copy in MOC 1913, Box 61, File 61/1, 15-07-01/1, PARC; LGB to Mayor Simon, 20 September 1909, copy in MOC 1911, Box 24, File 24/6, 15-07-28/3, PARC; WPD/DAR: 25 September, 15, 28 october, 1 December 1908, 5 January, 9, 11 February, 1 May, 17 August, 5 September 1909, 20 September 1911, 1 June, 24 october 1912; LGB visit to Vancouver, B.C., Police Committee file, copy in CD 1911, Box 116, File 116/6, 19-01-08/2, PARC;

"Mrs. Lola G. Baldwin Heads Police Matron League," unidentified newsclipping, 3 November 1912, copy in Scrapbook 10, p. 116, Oregon Historical Center; LGB to Mayor-elect Albee, 7 June 1913, copy in MOC 1913, Box 61, File 61/1, 15-07-01/1, PARC.

15. LGB files, passim.

16. Peggy Pascoe, Relations of Rescue: The Search for Female Moral Authority in the American West, 1874-1939 (New York: oxford University Press, 1990), pp. 185-212.

17. Ibid., pp. 192, 198 . 
18. Ibid., p. 198; Pivar, p. 261; Fass, p. 15.

19. Robert H. Wiebe, The Search For Order, 1877-1920 (New York: Hill and Wang, 1967), p. 212; Pivar, "Cleansing," Proloque, p. 33 . 


\section{REFERENCES}

\section{PRIMARY SOURCES}

\section{Archives}

Oregon Historical Center

Reports of Portland Vice Commission, 1912-1913

Portland Archives and Records Center

Portland Mayor's Office Correspondence, 1904-1922

Portland City Council Documents, 1904-1922

City of Portland Annual Reports, 1904-1916

Polk's City of Portland Directories, 1904-1914

Portland City Ordinances, 1908-1918

Portland Police Historical Society

Women's Protective Division Daily Activity

Reports, 1908-1913

Lola G. Baldwin Miscellaneous Correspondence

\section{Newspapers}

oregonian, 1905-1922, 1948-1957

Portland Evening Telegram, 1905-1922

Oregon Journal, 1905-1922, 1948-1957

\section{Books and Articles}

Addams, Jane. $\underline{A} \underline{\text { New }}$ Conscience and an $\underline{\text { Ancient Evil. New }}$ York: MacMillan, 1912. 
Barrett, Kate waller. Some Practical Suggestions on the Conduct of a Rescue Home. 1903; reprint, New York: Arno, 1974 .

Calahane, Cornelius F. The Policeman. 1923; reprint, New York: Arno, 1970.

Davis, Katherine B. "Social Hygiene and the War: Woman's Part in Social Hygiene." Social Hygiene 4, no. 4 (October 1918): 525-560.

Fosdick, Raymond B. "The Annual Report of the Commission on Training Camp Activities." Social Hyqiene 5, no. 2 (April 1919): 265-268.

- American Police Systems. 1920. Reprint.

Montclair, N.J.: Patterson-Smith, 1969.

- et al. Criminal Justice in Cleveland: Cleveland Foundation Reports. Edited by Roscoe Pound and Felix Frankfurter. 1922. Reprint. Montclair N.J.:

Patterson-Smith, 1968 .

Foster, William T. ed. The Social Emergency: Studies in Sex Hygiene and Morals. Boston: Houghton-Mifflin, 1914.

General Laws of oregon, Vols. 1903-1913. Salem: State of Oregon.

Johnson, Bascom. "The Injunction and Abatement Law." Social Hygiene 1, no. 2 (March 1915): 231-256.

Johnson, Paul B. "Social Hygiene and the War." Social Hygiene 4, no. 1 (January 1918): 91-137.

Mayer, Joseph. "The Passing of the Red Light District: Vice Investigations and Results." Social Hygiene 4, no. 2 (April 1918): 197-209.

"Pioneer Experiences." Social Hygiene 4, no. 4 (October 1919): 567-589.

Rippin, Jane D. "Social Hygiene and the War: Work With Women and Girls." Social Hygiene 5, no. 1 (January 1919): $125-136$.

Woolston, Howard B. Prostitution in the United States. 1921; reprint, Montclair, N.J.: Patterson-Smith, 1969. 
Oral Interviews

o'Hara, sgt. Ralph, personal interview with author, Portland Police Museum, January, 1991.

SECONDARY SOURCES

Books and Articles

Burnham, John C. "The Progressive Era Revolution in

American Attitudes Toward Sex." Journal of American

History $59(1973)$ : 885-908.

Caiden, Gerald E. Police Revitalization. Lexington, Mass.: D. C. Heath, 1977 .

D'Emilio, John, and Estelle B. Freedman. Intimate Matters: $\underline{A}$ History of Sexuality in America. New York: Harper and Row, 1988 .

de Young, Mary. "Help, I'm Being Held Captive! The White Slave Fairy Tale of the Progressive Era." Journal of American Culture 6, 1 (Spring 1983): 96-99.

Erenberg, Lewis A. Steppin' Out: New York Nightlife and the Transformation of American culture. Chicago: University of Chicago Press, 1984 .

Fass, Paula S. The Damned and the Beautiful: American Youth in the 1920s. New York: Oxford University Press, 1977.

Flink, James J. The Automobile Age. Cambridge, Mass.: MIT Press, 1990 .

Freedman, Estelle B. Their Sisters' Keepers: Women's Prison Reform in America, 1830-1930. Ann Arbor, Mich.: University of Michigan Press, 1981.

Horne, Peter. Women in Law Enforcement. Springfield, I11.: Charles C. Thomas, 1980 .

Kirschner, Don S. The Paradox of Professionalism: Reform and Pub1ic Service in Urban America, 1900-1940. New York: Greenwood Press, 1986 .

Liebman, Robert, and Michael Polen. "Perspectives on Policing in Nineteenth-Century America." Social Science History 2, 3 (Spring 1978): 346-360.

Lubove, Roy. "The Progressives and the Prostitute." Historian 24 (May 1962): 308-330. 
- The Professional Altruist: The Emergence of Social Work as a Career, 1880-1930. Cambridge, Mass.: Harvard University Press, 1965.

May, Lary. Screening out the Past: The Birth of Mass Culture and the Motion picture Industry. New York: Oxford University Press, 1980.

MacColl, E. Kimbark, with Harry H. Stein. Merchants, Money, and Power: The Portland Establishment, 1843-1913. Portland, Oreg.: The Georgian Press, 1988 .

Martin, Susan E. Breaking and Entering: Policewomen on Patrol. Berkeley and Los Angeles: University of California Press, 1980.

Moynihan, Ruth B. Rebel for Rights: Abigail Scott Duniway. New Haven: Yale University Press, 1983.

Noble, David W. The Progressive Mind, 1890-1917. Revised edition, Minneapolis: Burgess, 1981.

O'Neill, William L. The Progressive Years: America Comes of Age. New York: Harper and Row, 1975.

Owings, Chloe. Women Police: A Study of the Development and Status of the Women Police Movement. 1925; reprint, Montclair, N.J.: Patterson-Smith, 1969.

Pascoe, Peggy. Relations of Rescue: The Search for Female Moral Authority in the American West, 1874-1939. New York: Oxford University Press, 1990.

Peiss, Kathy. Cheap Amusements: Working Women and Leisure in Turn-of-the-Century New York. Philadelphia: Temple University Press, 1986.

Pivar, David J. Purity Crusade: Sexual Morality and Social Control, 1868-1900. Westport, Ct.: Greenwood Press, 1973.

- "Cleansing the Nation: The War on Prostitution, 1917-1921." Proloque 12 (Spring 1980): 29-40.

Roby, Pamela A. "Politics and Prostitution: A Case Study of the Formulation, Enforcement, and Judicial

Administration of the New York State Laws on Prostitution." Ph.D. diss., New York University, 1971.

Rosen, Ruth. The Lost Sisterhood: Prostitution in America, $1900-1918$. Baltimore: Johns-Hopkins University Press, 1982 . 
Rosenberg, Rosalind. Beyond Separate Spheres: Intellectual Roots of Modern Feminism. New Haven: Yale University Press, 1982 .

Schlossman, Steven, and Stephanie Wallach. "The Crime of Precocious Sexuality: Female Juvenile Delinquency in the Progressive Era." Harvard Educational Review 48 (February 1978): 65-94.

Sklar, Robert. Movie-Made America: A Cultural History of American Movies. New York: Vintage Press, 1976.

Smith, Elizabeth S. Breakthrough: Women in Law Enforcement. New York: Walker and Co., 1982.

Smith, Helen $K .$, ed. With Her Own Wings: Historical Sketches, Reminiscences, and Anecdotes of Pioneer Women. $2 d$ ed. Portiand, oreg.: Beattie, 1974 .

Walker, Samuel. A Critical History of Police Reform: The Emergence of $\frac{\overline{\text { Professionalism. }}}{\text { Lexington, }}$ Mass.: D. C. Heath, 1977 . - The Police in America. New York: McGraw-Hill, 1983. - Popular Justice: A History of American Criminal Justice. New York: Oxford University Press, 1980.

Wiebe, Robert $H$. The Search for order, 1877-1920. New York: Hill and Wang, 1967.

Wilson, 0tto. Fifty Years Work With Gir1s: The Life of Dr. Kate Waller Barrett. 1933; reprint, New York: Arno, 1974 . 